\title{
1 Refining the domain architecture model of the replication origin firing factor Treslin/TICRR
}

2

3 Pedro Ferreira ${ }^{1 \wedge}$, Luis Sanchez-Pulido ${ }^{2 \wedge}$, Anika Marko ${ }^{1}$, Chris P Ponting ${ }^{2}$, Dominik Boos ${ }^{1^{*}}$

4

$5 \quad{ }^{1}$ Vertebrate DNA Replication Lab, Centre for Medical Biotechnology, University of Duisburg-Essen, 45141 Essen,

6 Germany

$7 \quad{ }^{2}$ Medical Research Council Human Genetics Unit, IGMM, University of Edinburgh, Edinburgh EH9 3JR,

8 Scotland, UK

9 equal contribution

10 * corresponding author: dominik.boos@uni-due.de; phone: +49 201183 4132, ORCID: https://orcid.org/0000-

$11 \quad \underline{0003-0018-4375}$

12

13 Short title: Domain architecture of Treslin/TICRR

14

15 Key words: DNA Replication, origin firing, Metazoa, Treslin/TICRR, SId3, Ku70/80

16 


\section{Abstract}

18 Faithful genome duplication requires appropriately controlled replication origin firing. The

19 metazoan Treslin/TICRR origin firing factor and its yeast orthologue Sld3 are regulation hubs

20 of origin firing. They share the Sld3-Treslin domain (STD) and the adjacent TopBP1/Dpb11

21 interaction domain (TDIN). We report a revised domain architecture model of Treslin/TICRR.

22 Complementary protein sequence analyses uncovered Ku70-homologous $\beta$-barrel folds in the

23 Treslin/TICRR middle domain ( $M$ domain) and in Sld3. Thus, the Sld3-homologous

24 Treslin/TICRR core comprises its three central domains, M domain, STD and TDIN. This SId3-

25 core is flanked by non-conserved terminal domains, the CIT (conserved in Treslins) and the C-

26 terminus. We also identified Ku70-like $\beta$-barrels in MTBP and SId7. Our binding experiments

27 showed that the Treslin $\beta$-barrel mediates interaction with the MTBP $\beta$-barrel, reminiscent of

28 the homotypic Ku70-Ku80 dimerization. This binding mode is conserved in the Sld3-SId7

29 dimer. We used Treslin/TICRR domain mutants to show that all Sld3-core domains and the

30 non-conserved terminal domains fulfil important functions during origin firing in human cells.

31 Thus, metazoa-specific and widely conserved molecular processes cooperate during origin

32 firing in metazoa. 


\section{Introduction}

35 Accurate and complete DNA replication guarantees faithful genetic inheritance. It requires complex regulation of replication origin firing to ensure 1) efficient firing to avoid nonreplicated gaps, and 2) appropriately controlled firing in space and time to facilitate the metazoan genome replication program and coordinate replication with other chromatin processes like transcription (Berezney et al 2000, Boos \& Ferreira 2019, Dileep et al 2015, Helmrich et al 2013, Petryk et al 2016, Ryba et al 2010).

Replication initiation is a two-step process in eukaryotes. The first step, origin licensing, in G1 phase is the formation of pre-replicative complex (pre-RC), the loading of the $\mathrm{Mcm} 2-7$ replicative helicase onto double-stranded DNA (Evrin et al 2009, Remus et al 2009). In pre$\mathrm{RCs}$, the Mcm2-7 complex does not have helicase activity to avoid premature DNA unwinding in G1. The second step is origin firing, the conversion of pre-RCs into two bidirectional replisomes. Firing occurs $S$ phase-specifically due to its dependency on S phase cyclindependent kinases (S-CDK) and Dbf4-dependent kinase (DDK), whose activities increase at the G1-S transition. During firing, pre-RCs are first remodelled into pre-initiation complexes (pre-ICs) (Miyazawa-Onami et al 2017, Yeeles et al 2015, Zou \& Stillman 1998) that then mature into the active Cdc45-Mcm2-7-GINS-DNA polymerase epsilon (CMGE) helicase (Abid Ali et al 2017, Douglas et al 2018, llves et al 2010, Langston et al 2014). DNA synthesis requires assembly of additional replisome factors and primer synthesis (Yeeles et al 2017). 
DDK (Deegan et al 2016, Heller et al 2011). SId3 recruits Cdc45 via its central STD domain (Itou

et al 2014, Kamimura et al 2001) (Fig. 1). Sld3 utilizes its TDIN region to bind to Dpb11

60 (TopBP1/Cut5/Mus101 in higher eukaryotes) in an interaction that depends on

61 phosphorylation at two CDK sites in the TDIN (Boos et al 2011, Zegerman \& Diffley 2007).

62 Dpb11 also binds CDK-phosphorylated Sld2 (RecQL4 in higher eukaryotes). Dpb11 and Sld2

63 form the pre-loading complex together with GINS and DNA polymerase epsilon (Muramatsu

64 et al 2010). The resulting intermediate structure is called pre-IC. Then, SId3, Dpb11 and SId2 dissociate and the CMGE helicase forms.

67 In addition to cell cycle kinases, the DNA damage checkpoint also controls origin firing at the pre-IC step. Checkpoint kinase phosphorylation of Sld3 and Dbf4 inhibit pre-IC formation to avoid mutations through replicating damaged templates (Duch et al 2011, Lopez-Mosqueda et al 2010, Zegerman \& Diffley 2010). Recently, it has become clear that more subtle regulation of pre-IC factor activity and levels are critical for faithful genome duplication in yeast (Mantiero et al 2011, Reusswig et al 2016, Tanaka \& Araki 2011, Tanaka et al 2011).

Many fundamental processes of yeast origin firing are conserved in vertebrates. All yeast origin firing factors have orthologues in higher eukaryotes (Kohler et al 2019). In addition, cell cycle regulation by CDK through Treslin/SId3 binding to TopBP1/Dpb11 and also firing inhibition upon DNA damage through suppression of the Treslin/SId3-TopBP1/Dpb11 interaction are both conserved (Boos et al 2011, Guo et al 2015, Kumagai et al 2010; 2011, Mu et al 2017, Sansam et al 2010). 
82 Zegerman 2015). This suggests that, despite the described conservation, metazoa and fungi

83 have evolved specific origin firing processes. Whilst it has been shown that some higher eukaryote-specific domains of MTBP and TopBP1 are required for efficient DNA synthesis (Kohler et al 2019, Kumagai et al 2010), the situation for Treslin/TICRR remains less clear.

Characterisation of the protein domains that are specific to higher eukaryotes is essential for defining how origin firing processes in these cells diverge from the established yeast model.

The two central STD and TDIN domains of Treslin/TICRR show sequence-based evidence for homology with Sld3 (Fig. 1) (Boos et al 2011, Itou et al 2014, Sanchez-Pulido et al 2010). The molecular functions of the STD of Treslin/TICRR and whether this region is essential for replication remain unknown. Its homology with Sld3 suggests that it might support origin firing through interaction with Cdc45 (Itou et al 2014). The TDIN of Treslin/TICRR is a conserved region containing two CDK phosphorylation sites for TopBP1 binding (Boos et al 2011, Kumagai et al 2011). Like the SId3-TDIN the Treslin/TICRR-TDIN forms a direct binding surface for BRCA1 C-terminal repeat domains (BRCT) in TopBP1/Dpb11 (Boos et al 2011, Kumagai et al 2011, Zegerman \& Diffley 2007).

The Treslin/TICRR domains N- and C-terminal of STD and TDIN (Fig. 1) have not been shown to be conserved with Sld3. The M domain shares the ability to bind to MTBP/SId7 with the Nterminal region of SId3, and it is required for replication in human cells (Itou et al 2015, Kohler et al 2019). It came as a surprise that sequence conservation with SId3 was not detected for the Treslin/TICRR M domain, because the interacting regions in MTBP and SId7, respectively, show homology via remote but statistically significant sequence similarity (Kohler et al 2019). 
plants (Sanchez-Pulido et al 2010). Sequence analysis predicts that this Treslin/TICRR C-

107 terminal region is largely unstructured, with well-conserved stretches of amino acids and more divergent regions alternating. This region binds Chk1 and BRD2/4 (Fig. 1), but these activities are not essential for DNA synthesis in cultured human cells (Guo et al 2015, Sansam et al 2018). The N-terminal CIT is conserved in both metazoans and plants, but not present in fungi (Sanchez-Pulido et al 2010). Whether the CIT functions in replication is unknown.

113 We here define the essential SId3-like core of Treslin/TICRR as the three M, STD and TDIN 114 domains, flanked by higher eukaryote-specific terminal domains. Moreover, we characterise structurally and functionally the $M$ domain and the higher eukaryote-specific terminal 116 regions.

\section{Results}

The M domain, the STD and the TDIN domain constitute the essential core of Treslin/TICRR

We first sought to better define the essential core domains of Treslin/TICRR for replication.

121 Mutations of Treslin/TICRR previously showed that the MTBP/SId7-binding M domain and the

122 TopBP1/Dpb11-binding TDIN perform essential functions during origin firing in human cells

123 (Boos et al 2011, Boos et al 2013, Kumagai \& Dunphy 2017). In contrast, the requirement of 124 the Sld3-homologous STD for replication had not previously been addressed in higher 125 eukaryotes. To test this, we used incorporation of the nucleotide analogue 5-bromo-2'deoxyuridine (BrdU) into nascent DNA of cultured human cells in an established RNAi-

127 replacement system (Boos et al 2011, Boos et al 2013). U2OS cell clones stably expressing 128 siRNA-resistant Treslin/TICRR wild type (WT) or STD-deletion mutants ( $\triangle S T D$, amino acids 129 717-792 deleted) to similar levels (Fig. 2A) were treated with control siRNA (siCtr) or 
130 Treslin/TICRR siRNA (siTreslin). $72 \mathrm{~h}$ after transfection cells were pulse-labelled with BrdU,

131 stained with anti-BrdU-FITC and propidium iodide (PI), and analysed by flow cytometry.

132 Parental U2OS cells and control cell lines expressing the inactive non-TopBP1 interacting CDK

133 site mutant Treslin/TICRR-2PM showed severely reduced BrdU incorporation levels compared

134 to siCtr-treated cells (Fig 2B). Whilst Treslin/TICRR-WT rescued BrdU incorporation, three

135 independent clones expressing Treslin/TICRR- $\triangle$ STD (clones 11, 17 and 21) showed strong

136 defects in supporting replication (Fig 2B). Quantification of replicates (Fig. 2C) confirmed

137 these observations and proved reproducibility of our BrdU quantification method (Boos et al

138 2013, Ferreira et al 2021, Kohler et al 2019). Treslin/TICRR- $\Delta$ STD clone 21 rescued replication

139 somewhat better (50 \% replication) than clones 11 and 17 (approximately $30 \%$ replication;

$1402 \mathrm{PM}$ and no-transgene controls about 30\%), exemplifying our observation that individual

141 clones expressing the same transgene showed some variability that probably arise through

142 clonal selection. We then tested if specifically the origin firing step of replication is impaired

143 in Treslin- $\triangle$ STD cells by analysing origin licensing and replisome formation on chromatin.

144 Western blotting of chromatin fractions using anti-Mcm2 antibodies showed that replication

145 origin licensing occurred normally in the $\mathrm{G} 1$ phase ( $4 \mathrm{~h}$ after Nocodazole release) in

146 Treslin/TICRR- $\triangle$ STD cells. In contrast, origin firing did not occur in the absence of the STD

147 domain as indicated by severely reduced S phase-specific (12 h) Cdc45 and PCNA loading onto

148 chromatin (Fig 2D). The loss of replication activity is not a consequence of a delay in S phase

149 entry, because Cyclin A accumulated normally in Treslin- $\Delta$ STD cells $12 \mathrm{~h}$ after release (Fig 2D).

150 STD deletion neither lead to gross misfolding of Treslin/TICRR nor affected the described

151 activities of the neighbouring $M$ and TDIN domains, because Treslin- $\Delta$ STD

152 immunoprecipitated MTBP (Boos et al 2013) and TopBP1 (Fig. S1) normally. We concluded

153 from these RNAi-rescue experiments that deleting the STD severely compromises replication 
154 origin firing in U2OS cells. Thus, the STD is part of the essential set of core domains of

155 Treslin/TICRR, together with the $M$ and TDIN domains.

157 Characterisation of the region N-terminal to the Treslin/TICRR-STD by protein sequence

analysis

We then sought to better understand the region N-terminal to the STD of Treslin/TICRR, because it has no described sequence conservation with SId3, but contains the M domain that

that an increase in protein sequence and structure information and improved computational

Sanchez-Pulido et al 2010).

First, we conducted a JackHMMER iterative search with amino acids 1-600 of the human constructed a full-length multiple sequence alignment of Treslin/TICRR family members.

172 During this process, we identified a N-terminal region of Treslin/TICRR (approximately amino acids 1-600) that is well-conserved across the animal kingdom, including earlier branching animals such as echinoderms, molluscs, annelids, and placozoans (Trichoplax sp.).

176 Then we used those sub-regions of this alignment that exhibited the highest levels of 
178 (HHpred) (Eddy 1996, Finn et al 2011, Soding et al 2005). In particular, we undertook HHpred

179 searches against the PDB70 profile database (Soding et al 2005), using the previously

180 identified CIT region that is conserved between animal and plant Treslins (corresponding to

181 residues 4 to 254 of human Treslin/TICRR) (Sanchez-Pulido et al 2010) (Fig 1). This search

182 identified the Treslin/TICRR N-terminal domain as a von Willebrand factor type A (vWA)

183 domain (also known as a Rossmann fold), with a highly significant match to the vWA domain

184 of human complement factor B protein (PDB-ID: 3HRZ_D) (Janssen et al 2009) ( $E$-value $=9.2$

$185 \times 10^{-3}$; true positive probability of $97 \%$ ) (Fig S2). In support of homology, the next most

186 statistically significant matches were to more than ten additional members of the vWA

187 domain superfamily, such as: human protein transport protein Sec23A (PDB-ID: 2NUT_A)

188 (Mancias \& Goldberg 2007), human Integrin $\beta-8$ (PDB-ID: 6DJP_B)(Cormier et al 2018), and yeast DNA repair protein Ku70 (PDB-ID: 5Y58_E) (Chen et al 2018). The secondary structure prediction for this region of Treslin/TICRR showed good agreement with the known secondary structure known of diverse members of the vWA superfamily (Jones 1999) (Fig S2).

The vWA domain consists of alternating $\beta$-strand and $\alpha$-helix secondary structural elements,

vWA domain using sequence comparison. 
We next focused our bioinformatic analysis on the poorly characterised $\mathrm{M}$ domain. Although

this Treslin/TICRR domain carries one of its core functions, one that is shared with SId3 (the essential binding to MTBP/SId7), its homology with Sld3 had not previously been demonstrated. HHpred searches of this region against the PDB70 profile database (Soding et al 2005) yielded statistically significant evidence of sequence similarity of Treslin/TICRR amino acids 341 to 426 to yeast Ku70 (PDB-ID: 5Y58_E) (Chen et al 2018) (E-value $=0.3$; true positive probability of $88 \%$ ) (Fig $3 A$ ). In further support of homology, the next most statistically significant matches were to three further members of the Ku family, namely yeast Ku80 (PDB-ID: 5Y58_F) (Chen et al 2018), human XRCC5 (PDB-ID: 1JEY_B), and human XRCC6

A structural analysis between Treslin/TICRR and Ku70 confirmed the presence of a Ku70-like $\beta$-barrel domain. Initially, the Treslin/TICRR $\beta$-barrel domain appeared to lack two consecutive anti-parallel $\beta$-strands (labelled 1 and 2 in Fig S3), which contribute to the domain's core (Walker et al 2001). The low sequence similarity between Ku70 and Treslin/TICRR in these regions and a long insertion in the Ku70 $\beta$-barrel between $\beta$-strands 2 and 3 initially confounded our automatic methods. Nevertheless, results from the RaptorX coevolutionbased contact prediction method allowed the Treslin/Ku70 alignment to be extended by 50 residues $\mathrm{N}$-terminally, in which the two previously-missing $\beta$-strands in Treslin/TICRR became apparent due to a strong anti-parallel co-evolution signal (Fig S3) (Jones 1999, Wang et al 2017). To investigate whether fold recognition analysis generated consistent results, we submitted this conserved region of the human Treslin/TICRR protein to the fold assignment 
consistently recognised human Ku70 (PDB-IDs: 1JEQ_A) and the Ku70-like $\beta$-barrel in the

SPOC domain (PDB-ID: 1OW1) as best templates.

In summary, three independent lines of enquiry, (i) sequence conservation (HHpred), (ii) a coevolution-based contact prediction (RaptorX), and (iii) threading (I-TASSER), provided strong and consistent evidence that the conserved $\mathrm{M}$ domain in Treslin/TICRR folds as a Ku70-

\section{A Ku70-like 6-barrel domain is also present in Sld3 and SId7/MTBP}

Using DALI structural comparison searches we also identified previously unappreciated Ku70-

like $\beta$-barrels in both the SId3 binding domain of yeast SId7 and the SId7-binding domain of

is truncated, containing only five $\beta$-strands. In summary, the SId3/SId7 heterodimer forms in

two structurally similar domains.

240 The homology of the $\beta$-barrel domains for SId3 and SId7 and their respective human

241 orthologues Treslin/TICRR and MTBP (Boos et al 2011, Boos et al 2013, Kohler et al 2019,

242 Kumagai \& Dunphy 2017, Sanchez-Pulido et al 2010) suggest that the Ku70-like $\beta$-barrel newly

243 identified in Treslin/TICRR is an excellent candidate for being the principal region

244 (heterodimerization domain) that interacts with MTBP. 
247 To test whether Treslin/TICRR and MTBP may indeed interact via a homotypic Ku70/Ku80-

248 type $\beta$-barrel-dependent interaction, we characterised this interaction. Previous biochemical

249 and structural studies had shown an involvement of MTBP/SId7 elements, now established

250 here as part of the $\beta$-barrel, in the interaction with Treslin/SId3 (Itou et al 2015, Kohler et al

251 2019).

252

253 We showed previously that deleting two large regions of the Treslin/TICRR M domain, amino acids 265-408 (M1) or 409-593 (M2), compromised MTBP binding (Boos et al 2013). Deleting M2 abrogated and deleting M1 severely weakened this interaction. Figure 3B shows that a fragment of Treslin/TICRR containing amino acids 260-671 that included M1 and M2 coimmunoprecipitated with endogenous MTBP in lysates of transfected 293T cells. To test the involvement of the Ku70-like $\beta$-barrel in Treslin/TICRR, we deleted amino acids 370-400 and 401-420, each containing portions that aligned with SId3 regions that entertain direct contacts with Sld7 (Fig 3A, * symbols) (Itou et al 2015). Both deletions severely compromised the interaction with MTBP (Fig 3B), indicating that the $\beta$-barrel is required.

We found that a region C-terminal to the Ku70-like $\beta$-barrel is also required for MTBP interaction. The N-terminal 557 amino acids of Treslin/TICRR, but not the N-terminal 486 amino acids, bound to MTBP (Fig 3B). Small deletions revealed that the amino acids 518-543, but not 487-517 and 545-557, are required for MTBP binding (Fig 3B). In yeast SId3, a short sequence approximately 35 amino acids C-terminal to the $\beta$-barrel also contains six amino acids that directly contact SId7 (Itou et al 2015). We conclude that the Ku70-like $\beta$-barrel in 
272 Together, our analysis of the N-terminal 600 amino acids of Treslin/TICRR revealed that the structurally conserved part with SId3 includes the K70/80-like $\beta$-barrel in the $M$ domain. Thus,

274 the central part of the Treslin/TICRR protein including the M, STD and TDIN domains constitutes a core that is homologous to SId3, flanked by Treslin/TICRR-specific terminal domains.

279 We next wanted to test whether the SId3-like Treslin/TICRR core is sufficient to support replication in human cells or whether it requires the higher eukaryote-specific CIT and C-

281 terminal domains. We performed BrdU-PI flow cytometry upon RNAi-replacement of

282 Treslin/TICRR using mutants that lacked either the CIT (Treslin/TICRR- $\Delta C I T$, amino acids 1-264

283 deleted), the C-terminal region (Treslin/TICRR- $\Delta$ C853, C-terminal 853 amino acids deleted), or both (Treslin/TICRR-core) (Fig. 4A). Treslin/TICRR- $\Delta$ CIT and Treslin/TICRR- $\Delta$ C853 cells showed relatively normal BrdU-PI profiles compared to Treslin/TICRR-WT cells, with S phase populations clearly separated from G1 and G2/M cells by higher BrdU signal intensities (Fig.

4B). Quantification of multiple independent experiments indicated mild reductions in confirmed these results (Fig. S4A, B, D and E), although, as described for Treslin/TICRR- $\triangle$ STD, there was some clonal variability, with one of three $\Delta \mathrm{C} 853$ clones (no. 29) rescuing like

291 Treslin/TICRR-WT (Fig. S4E). Expression levels of Treslin/TICRR- $\Delta$ C853 clones were similar or higher than Treslin/TICRR-WT (Fig S4B and D).

293 Surprisingly, the Treslin/TICRR-core mutant was inactive. BrdU incorporation in Treslin/TICRR- 
C, additional clones in Fig S5A-C). This indicated that, albeit individually non-essential for

replication, simultaneous deletion of both terminal regions had an additive or even synergistic effect on DNA replication. We concluded that the Sld3-like core domains of Treslin/TICRR require the $\mathrm{CIT}$ domain and the $\mathrm{C}$-terminal region to support replication in human cells.

The CIT cooperates with amino acids 1057-1257 in the C-terminus to support origin firing.

We then tested which part of the C-terminal region cooperates with the $\mathrm{CIT}$, and whether the cooperation depends on the described binding activities for Chk1 and BRD2/4. We successively truncated the C-terminal sequence in combination with CIT deletion. Truncating neither the Chk1- (Treslin/TICRR- $\Delta$ CIT/ $\Delta$ C99) (Guo et al 2015) nor the Chk1- and BRD2/4binding domains (Treslin/TICRR- $\Delta \mathrm{CIT} / \Delta \mathrm{C} 651$ ) (Sansam et al 2018) recapitulated the synergistic effect (Fig 4A-C; additional clones in Figs S5 and S6). These double-deletion mutants supported replication to a level similar to Treslin/TICRR- $\Delta$ CIT. The C-terminal truncations Treslin/TICRR- $\Delta$ C651 and $\Delta$ C99 (that contained the CIT) did not greatly affect BrdU incorporation (Figs S4C and S6B). We confirmed these results with two independent double-deletion mutants: Treslin/TICRR- $\Delta$ CIT/ $\Delta$ C309 that contains the BRD2/4 binding site, and Treslin/TICRR- $\Delta \mathrm{CIT} / \Delta \mathrm{C} 394$ that does not (Fig S6A, D and E).

Treslin-core did not support replication, as described above. To test whether the known core activities of Treslin/TICRR are intact in the Treslin/TICRR-core protein we tested association with MTBP and TopBP1. Treslin/TICRR-core and $\triangle$ C853 co-immunoprecipitated TopBP1 from 293 cell lysates similarly as Treslin/TICRR- $\Delta$ C651 (with or without CIT), suggesting that C-

317 terminal deletion of the important amino acids 1057-1257 did not detectably compromise 318 TopBP1 binding (Fig S7, lanes 4-7). Comparison of Treslin/TICRR-core and $\Delta$ C853 with 
319 Treslin/TICRR-full-length was difficult because of differences in expression levels and blotting

320 efficiency in transient transfections as a result of considerable size differences. Treslin/TICRRcore also bound MTBP. Some experiments (that had the same limitations as explained for TopBP1 binding experiments) suggested slightly less MTBP bound to Treslin/TICRR-core than to Treslin/TICRR-WT (Figs 4D and S6), which could indicate that the vWA domain-containing (Walker et al 2001). We cannot formally rule out that the mild reduction of MTBP binding fully explains the strong replication deficiency of Treslin/TICRR-core, although this is less likely.

We conclude that two higher eukaryote-specific Treslin/TICRR regions (specifically, CIT and the C-terminal amino acids 1057-1257) have important functions in replication.

Subtle particularities in cell cycle profiles of Treslin/TICRR-core cells suggested that this mutant may have other defects than cells lacking Treslin/TICRR function. For example, a delay in S phase entry in Treslin/TICRR-core cells could explain the occasionally observed decrease of the S phase sub-population (Fig S5C, clone 41). To exclude secondary effects of long-term siRNA treatment as much as possible, we tested whether Treslin/TICRR-core cells showed a specific defect in origin firing in the first $\mathrm{S}$ phase after replacing endogenous with transgenic Treslin/TICRR. To this end, we released Treslin/TICRR-core-expressing cells and U2OS control cells from a thymidine arrest into a nocodazole block and treated them with siRNA such that they completed S phase before siTreslin could take effect. Upon nocodazole wash-out, U2OS 
343 G1 phase, as indicated by 2 C DNA content at the $4 \mathrm{~h}$ time point (Fig 5A). As usual, a

344 subpopulation of cells released from the arrest with a delay. Subpopulations of siCtr-treated

345 U2OS cells and siTreslin-treated Treslin/TICRR-WT cells had started BrdU incorporation $12 \mathrm{~h}$

346 after nocodazole release. The fastest of these replicating cells had completed $30-50 \%$ of

347 genome duplication, as judged by PI signals, showing that they had been replicating for

348 several hours. In contrast, siTreslin-treated Treslin/TICRR-core and control cells did not

349 replicate. To test whether Treslin/TICRR-core expressing cells have defects specifically at the

350 origin firing step of DNA replication we analysed chromatin isolated from nocodazole-

351 released cells. The Mcm2-7 helicase loaded normally onto chromatin in siTreslin-treated

352 Treslin/TICRR-core G1 cells $(4 \mathrm{~h})$, showing that licensing was intact (Fig 5B). In contrast,

353 replisomes did not form more efficiently with Treslin/TICRR-core than in cells without

354 transgenic Treslin/TICRR, as indicated by PCNA and Cdc45 loading onto chromatin at $12 \mathrm{~h}$ in

355 Treslin/TICRR-WT cells, but not in Treslin/TICRR-core and control cells (Fig 5B). Cyclin A

blotting showed that Treslin/TICRR-core cells entered S phase normally (Fig 5C). We

concluded that Treslin/TICRR-core is specifically defective in origin firing.

Together, the Treslin/TICRR terminal regions that are specific to higher eukaryotes cooperate in parallel pathways towards an essential function in replication origin firing.

Discussion

We here present a characterization of a major origin-firing regulator, Treslin/TICRR, based on

364 its domain structure. Our insight that Treslin/TICRR and SId3 share similarity of the M domain

365 (Treslin/TICRR) and the N-terminus (SId3), respectively, completes the view that the three 
367 flanked by two Treslin/TICRR-specific terminal regions, the CIT and the C-terminal region (Fig.

368 6). These terminal regions are required for Treslin/TICRR's role in replication origin firing.

369 Important molecular activities of the core domains are known (Fig. 6). TDIN is essential for

370 replication in SId3 and Treslin/TICRR through CDK-mediated interaction with Dpb11 and

371 TopBP1, respectively (Boos et al 2011, Kumagai et al 2011, Tanaka et al 2007, Zegerman \&

372 Diffley 2007). The Sld3-STD binds Cdc45 (Itou et al 2014), an essential component of the

373 replicative CMG helicase. Although the Cdc45-binding activity of the STD has not been

374 investigated in Treslin/TICRR, conservation with SId3 suggests that this biochemical activity

375 might also be conserved (Itou et al 2014). We show here that the Treslin/TICRR-STD is

376 required for replication origin firing in cultured human cells, confirming that it has retained

377 important replication functions in humans. The $M$ domain of Treslin/TICRR is also essential

378 for replication in human cells and mediates the binding to MTBP (Boos et al 2013). Itou et al.

379 showed that the M domain-equivalent of SId3 constitutes a direct binding surface for Sld7

380 (Itou et al 2015). We reported earlier that the $M$ domain interacting region in MTBP, of Sld7 (Kohler et al 2019). Here we show that the interaction is mediated by Ku70-like $\beta$ barrel domains in Treslin/TICRR/SId3 and MTBP/SId7 (Itou et al 2015, Kohler et al 2019), suggesting that they form homotypic dimers comprised of structurally similar domains, similar to Ku70-Ku80 dimerization (Walker et al 2001). Uncharacterised important molecular activities might be situated in the regions between the domains with proven homology to of amino acids between the STD and TDIN of SId3 (Deegan et al 2016). 
We found that the SId3-like core of Treslin/TICRR was insufficient to support replication and origin firing in U2OS cells, whereas individual deletions of the Treslin/TICRR-specific CIT and region cooperate in parallel pathways to promote DNA replication origin firing. The simplest scenario is that $\mathrm{CIT}$ and the C-terminal region promote firing through functions in the molecular process of origin firing that have yet to be revealed. However, more indirect regulations that are specific to higher eukaryotes to facilitate faithful duplication of their specific protein domains of TopBP1 (Kumagai et al 2010) and MTBP (Kohler et al 2019).

The molecular activities underlying the proposed origin firing functions of $\mathrm{CIT}$ and the $\mathrm{C}$ terminal region remain unknown. Our mutants combining CIT-deletion and successive Crelevant activity is situated between amino acids 1057 and 1257 of human Treslin/TICRR. compromised in Treslin- $\Delta 853$. Although minor defects of Treslin/TICRR- $\Delta 853$ mutants in TopBP1 binding cannot be formally excluded we found no clear evidence for such a defect, regardless of whether or not the CIT was present. Also the fact that Treslin- $\Delta 853$ mutants that

412 contain the CIT have mild or no defects in supporting genome replication, depending on the 413 clone observed, argues against a significant TopBP1 binding deficiency. A relevant activity in 
414 the CIT for origin firing may be to support the binding to MTBP for two reasons: 1)

415 Treslin/TICRR-core and Treslin/TICRR- $\Delta$ CIT bound somewhat less well to MTBP (Fig 4D and

416 (Kohler et al 2019)), and 2) the CIT-equivalent domain in Ku70/80 makes a small contribution

417 to the Ku70/80 dimer interface (Walker et al 2001). This potential mild MTBP binding defect

418 may contribute to the inability of Treslin/TICRR-core to support origin firing. However, we find

419 it unlikely that such a moderate defect fully explains the strong replication deficiency of

420 Treslin/TICRR-core. This view is supported by the fact that a SId3/SId7-type interaction does

421 not necessarily require a CIT, because SId3-SId7 dimerization is CIT-independent. We cannot

422 formally exclude that Treslin/TICRR-core is prone to unfolding, although its normal expression

423 levels and good TopBP1 and MTBP binding capability speak against this. Other labs also

reported that C-terminally deleted Treslin/TICRR- $\Delta$ C651 supported replication well (Kumagai to support replication.

Interestingly, the CIT contains a vWA domain that is also shared by Ku70/Ku80 (Walker et al 2001). A specific molecular activity of the CIT cannot be delineated from the presence of this domain since vWA domains in other proteins have a variety of activities. The Ku70/80 similarity in the CIT and M domains supports speculation that, during evolution, Treslin/TICRR received the $\mathrm{CIT}$ and the $\mathrm{M}$ domain in a single event of genomic recombination. The identical order of the domains in the Ku70/80 proteins suggests that Ku proteins and Treslin/TICRR share an ancestral donor for these domains or that one of the two (Ku and Treslin/TICRR) was

435 the donor. Because animal and plant Treslins contain CITs, the last common ancestor of plants 
438 yeast evolution. In conclusion, the CIT may have been "donated" to Treslin/TICRR as one unit

439 alongside the Ku70-like $\beta$-barrel. Both together had the capability to form homotypic dimers

440 with MTBP. The minor (or absent) contribution of the CIT to MTBP binding presents the

441 possibility that it was retained in most branches of evolution due to another function

442 important for eukaryotic cells.

443

444 Determining the molecular and cellular functions of the non-core Treslin/TICRR domains will

445 help us better understand the specifics of origin firing in higher eukaryotes compared to yeast.

446 Because Treslin/TICRR mediates origin firing regulation, understanding its non-core domains

447 will likely be necessary to unravel how the complex higher eukaryotic cells coordinate origin

448 firing with other cellular processes.

449 


\section{Materials and Methods}

451

\section{Cell culture}

U2OS (ATCC-HTB-96) and 293T (ATCC CRL-11268) cells (both lines kind gift from The Crick institute tissue culture) were cultured in standard conditions in DMEM/high glucose (Life

454 Technologies, 41965062), $10 \%$ FCS, Penicillin/Streptomycin in $5 \% \mathrm{CO}_{2}$. Stable Treslin/TICRRexpressing U2OS cell clones were generated using a pIRES puro3-based vector system by random genome integration followed by selection on $0.3 \mu \mathrm{g} / \mathrm{ml}$ puromycin and picking of individual clones as described (Boos et al 2011, Boos et al 2013).

458

Analysis of unsynchronised and synchronous stable U2OS cells by BrdU-flow cytometry and

chromatin analysis

Endogenous Treslin/TICRR was replaced by siTreslin-resistant transgenes by transfecting

U2OS cells twice with Treslin/TICRR siRNA (GAACAAAGGTTATCACAAA) using RNAiMax (Life

$\mu \mathrm{M}$ BrdU for 30 min $72 \mathrm{~h}$ after the first transfection, harvested and stained with anti-BrdU-

471 signal. This replication signal was normalized to the replication signal of siCtr-treated cells of

472 the same cell clone to calculate the relative replication rescue. For analysis of synchronized

473 U2OS cells in Fig 2D and E cells were arrested by treatments with $2 \mathrm{mM}$ thymidine for $18 \mathrm{~h}$, 
474 release for $10 \mathrm{~h}$, and arrested once again with $2 \mathrm{mM}$ thymidine for $18 \mathrm{~h} .4 \mathrm{~h}$ after release from

475 the second thymidine block cells were treated with siRNA and $100 \mu \mathrm{g} / \mathrm{ml}$ nocodazole was

476 added for $16 \mathrm{~h}$. Release from the nocodazole arrest was done by washing the cells twice. After

477 cultivation for four or twelve hours, cells were harvested and analysed by BrdU-flow

478 cytometry as described above or by immunoblotting of whole cell lysates or chromatin-

479 enriched fractions as described (Boos et al 2013). For Fig 5, cells were instead treated with

480 siRNA and arrested by treatment with $2 \mathrm{mM}$ thymidine for $20 \mathrm{~h}$. Upon release from the

481 thymidine block, $100 \mu \mathrm{g} / \mathrm{ml}$ nocodazole was added for $18 \mathrm{~h}$. Cells were treated with the

482 second round of siRNA $4 \mathrm{~h}$ after the start of the nocodazole arrest.

Antibodies and affinity matrices

485

Antibodies against Treslin, MTBP and TopBP1 were described (Boos et al 2011, Boos et al

Covance); anti-GFP nanobodies (kind gift from Kirill Alexandrov); anti-GFP (mouse, JL-8,

Clonetech, 632381), anti-Mcm5 (rabbit, ab17967, abcam), anti-Cdc45 (rat, 3G10, kind gift

from Helmut Pospiech), anti-PCNA (mouse, sc-56, Santa Cruz), NHS sepharose (Fisher

$493293 T$ cells were transfected using standard calcium phosphate precipitation. $72 \mathrm{~h}$ after

494 transfection, cells were harvested and lysed in 5-10 times cell pellet volume using detergent

495 in native lysis buffers and douncing. Lysis buffer for anti-GFP immunoprecipitations in Fig S7 
Fig 4D lysis buffer was 20mM Hepes, $300 \mathrm{mM} \mathrm{NaCl}, 10 \%$ Glycerol, 0,1\%Triton, 2mM EDTA,

2mM mM ß-Mecaptoethanol, Complete EDTA-free protease inhibitors (Roche,

508 (purification system generously donated by Tim Hunt), $5 \mathrm{mM}$ ATP and $5 \mathrm{mM} \mathrm{MgCl} 2$ were added to the lysis buffers.

\section{Data availability}

512 The authors will comply with Nature Research policies for the sharing of research materials

513 and data.

\section{Acknowledgements}

516 We would like to thank the members of the S Westermann, $\mathrm{H}$ Meyer and D Boos labs for

517 discussion and sharing expertise and regents.

\section{Author contributions}

520 Conception and design: D.B., P.F.; Development of methodology: P.F., L.S.P. D.B.; Acquisition

521 of data: P.F., L.S.P, A.M., D.B.; Analysis and interpretation of data: P.F., L.S.P, A.M., C.P.P., 
bioRxiv preprint doi: https://doi.org/10.1101/2021.07.24.453613; this version posted July 24, 2021. The copyright holder for this preprint

(which was not certified by peer review) is the author/funder, who has granted bioRxiv a license to display the preprint in perpetuity. It is made available under aCC-BY-NC 4.0 International license.

522 D.B.; Writing and reviewing of the manuscript: D.B. (writing), L.S.P., C.P.P.; Study

523 supervision: D.B.

524

525 Conflict of interest

526 The authors declare no conflict interest.

527

528 
529

530

531

532

533

534

535

536

537

538

539

540

541

542

543

544

545

546

547

548

549

550

551

552

553

554

555

556

557

558

559

560

561

562

563

564

565

566

567

568

569

570

571

572

573

\section{References}

Abid Ali F, Douglas ME, Locke J, Pye VE, Nans A, Diffley JFX, Costa A. 2017. Cryo-em structure of a licensed DNA replication origin. Nat Commun. 8(1):2241. doi:10.1038/s41467017-02389-0

Berezney R, Dubey DD, Huberman JA. 2000. Heterogeneity of eukaryotic replicons, replicon clusters, and replication foci. Chromosoma. 108(8):471-484.

Boos D, Ferreira P. 2019. Origin firing regulations to control genome replication timing. Genes (Basel). 10(3) doi:10.3390/genes10030199

Boos D, Sanchez-Pulido L, Rappas M, Pearl LH, Oliver AW, Ponting CP, Diffley JFX. 2011. Regulation of DNA replication through sld3-dpb11 interaction is conserved from yeast to humans. Curr Biol. 21(13):1152-1157. doi:10.1016/j.cub.2011.05.057

Boos D, Yekezare M, Diffley JF. 2013. Identification of a heteromeric complex that promotes DNA replication origin firing in human cells. Science. 340(6135):981-984. doi:10.1126/science.1237448

Chen H, Xue J, Churikov D, Hass EP, Shi S, Lemon LD, Luciano P, Bertuch AA, Zappulla DC, Geli $\mathrm{V}$, et al. 2018. Structural insights into yeast telomerase recruitment to telomeres. Cell. 172(1-2):331-343 e313. doi:10.1016/j.cell.2017.12.008

Cormier A, Campbell MG, Ito S, Wu S, Lou J, Marks J, Baron JL, Nishimura SL, Cheng Y. 2018. Cryo-em structure of the alphavbeta8 integrin reveals a mechanism for stabilizing integrin extension. Nat Struct Mol Biol. 25(8):698-704. doi:10.1038/s41594-018-0093$x$

Deegan TD, Yeeles JT, Diffley JF. 2016. Phosphopeptide binding by sld3 links dbf4-dependent kinase to $\mathrm{mcm}$ replicative helicase activation. EMBO J. 35(9):961-973. doi:10.15252/embj.201593552

Dileep V, Ay F, Sima J, Vera DL, Noble WS, Gilbert DM. 2015. Topologically associating domains and their long-range contacts are established during early g1 coincident with the establishment of the replication-timing program. Genome Res. 25(8):1104-1113. doi:10.1101/gr.183699.114

Douglas ME, Ali FA, Costa A, Diffley JFX. 2018. The mechanism of eukaryotic cmg helicase activation. Nature. 555(7695):265-268. doi:10.1038/nature25787

Duch A, Palou G, Jonsson ZO, Palou R, Calvo E, Wohlschlegel J, Quintana DG. 2011. A dbf4 mutant contributes to bypassing the rad53-mediated block of origins of replication in response to genotoxic stress. J Biol Chem. 286(4):2486-2491. doi:10.1074/jbc.M110.190843

Eddy SR. 1996. Hidden markov models. Curr Opin Struct Biol. 6(3):361-365. doi:10.1016/s0959-440x(96)80056-x

Evrin C, Clarke P, Zech J, Lurz R, Sun J, Uhle S, Li H, Stillman B, Speck C. 2009. A doublehexameric mcm 2-7 complex is loaded onto origin DNA during licensing of eukaryotic DNA replication. Proc Natl Acad Sci U S A. 106(48):20240-20245. doi:10.1073/pnas.0911500106

Ferreira P, Hofer V, Kronshage N, Marko A, Reusswig KU, Tetik B, Diessel C, Kohler K, Tschernoster N, Altmuller J, et al. 2021. Mtbp phosphorylation controls DNA replication origin firing. Sci Rep. 11(1):4242. doi:10.1038/s41598-021-83287-w

Finn RD, Clements J, Eddy SR. 2011. Hmmer web server: Interactive sequence similarity searching. Nucleic Acids Res. 39(Web Server issue):W29-37. doi:10.1093/nar/gkr367 
574

575

576

577

578

579

580

581

582

583

584

585

586

587

588

589

590

591

592

593

594

595

596

597

598

599

600

601

602

603

604

605

606

607

608

609

610

611

612

613

614

615

616

617

618

Guo C, Kumagai A, Schlacher K, Shevchenko A, Shevchenko A, Dunphy WG. 2015. Interaction of chk1 with treslin negatively regulates the initiation of chromosomal DNA replication. Mol Cell. 57(3):492-505. doi:10.1016/j.molcel.2014.12.003

Heller RC, Kang S, Lam WM, Chen S, Chan CS, Bell SP. 2011. Eukaryotic origin-dependent DNA replication in vitro reveals sequential action of ddk and s-cdk kinases. Cell. 146(1):8091. doi:10.1016/j.cell.2011.06.012

Helmrich A, Ballarino M, Nudler E, Tora L. 2013. Transcription-replication encounters, consequences and genomic instability. Nat Struct Mol Biol. 20(4):412-418. doi:10.1038/nsmb.2543

Holm L, Sander C. 1995. Dali: A network tool for protein structure comparison. Trends Biochem Sci. 20(11):478-480. doi:10.1016/s0968-0004(00)89105-7

Ilves I, Petojevic T, Pesavento JJ, Botchan MR. 2010. Activation of the mcm2-7 helicase by association with cdc45 and gins proteins. Mol Cell. 37(2):247-258. doi:10.1016/j.molcel.2009.12.030

Itou H, Muramatsu S, Shirakihara Y, Araki H. 2014. Crystal structure of the homology domain of the eukaryotic DNA replication proteins sld3/treslin. Structure. 22(9):1341-1347. doi:10.1016/j.str.2014.07.001

Itou $\mathrm{H}$, Shirakihara $\mathrm{Y}$, Araki H. 2015. The quaternary structure of the eukaryotic DNA replication proteins sld7 and sld3. Acta Crystallogr D Biol Crystallogr. 71(Pt 8):16491656. doi:10.1107/S1399004715010457

Janssen BJ, Gomes L, Koning RI, Svergun DI, Koster AJ, Fritzinger DC, Vogel CW, Gros P. 2009. Insights into complement convertase formation based on the structure of the factor b-cobra venom factor complex. EMBO J. 28(16):2469-2478. doi:10.1038/emboj.2009.184

Jones DT. 1999. Protein secondary structure prediction based on position-specific scoring matrices. J Mol Biol. 292(2):195-202. doi:10.1006/jmbi.1999.3091

Kamimura Y, Tak YS, Sugino A, Araki H. 2001. SId3, which interacts with cdc45 (sld4), functions for chromosomal DNA replication in saccharomyces cerevisiae. Embo J. 20(8):20972107.

Kohler K, Sanchez-Pulido L, Hofer V, Marko A, Ponting CP, Snijders AP, Feederle R, Schepers A, Boos D. 2019. The cdk8/19-cyclin c transcription regulator functions in genome replication through metazoan sld7. PLoS Biol. 17(1):e2006767. doi:10.1371/journal.pbio.2006767

Kumagai A, Dunphy WG. 2017. Mtbp, the partner of treslin, contains a novel DNA-binding domain that is essential for proper initiation of DNA replication. Mol Biol Cell. doi:10.1091/mbc.E17-07-0448

Kumagai A, Shevchenko A, Dunphy WG. 2010. Treslin collaborates with topbp1 in triggering the initiation of DNA replication. Cell. 140(3):349-359. doi:10.1016/j.cell.2009.12.049

Kumagai A, Shevchenko A, Dunphy WG. 2011. Direct regulation of treslin by cyclin-dependent kinase is essential for the onset of DNA replication. J Cell Biol. 193(6):995-1007. doi:10.1083/jcb.201102003

Langston LD, Zhang D, Yurieva O, Georgescu RE, Finkelstein J, Yao NY, Indiani C, O'Donnell ME. 2014. Cmg helicase and DNA polymerase epsilon form a functional 15-subunit holoenzyme for eukaryotic leading-strand DNA replication. Proc Natl Acad Sci U S A. 111(43):15390-15395. doi:10.1073/pnas.1418334111 
619

620

621

622

623

624

625

626

627

628

629

630

631

632

633

634

635

636

637

638

639

640

641

642

643

644

645

646

647

648

649

650

651

652

653

654

655

656

657

658

659

660

661

662

663

Lopez-Mosqueda J, Maas NL, Jonsson ZO, Defazio-Eli LG, Wohlschlegel J, Toczyski DP. 2010. Damage-induced phosphorylation of sld3 is important to block late origin firing. Nature. 467(7314):479-483. doi:10.1038/nature09377

Makiniemi M, Hillukkala T, Tuusa J, Reini K, Vaara M, Huang D, Pospiech H, Majuri I, Westerling T, Makela TP, et al. 2001. Brct domain-containing protein topbp1 functions in DNA replication and damage response. J Biol Chem. 276(32):30399-30406.

Mancias JD, Goldberg J. 2007. The transport signal on sec22 for packaging into copii-coated vesicles is a conformational epitope. Mol Cell. 26(3):403-414. doi:10.1016/j.molcel.2007.03.017

Mantiero D, Mackenzie A, Donaldson A, Zegerman P. 2011. Limiting replication initiation factors execute the temporal programme of origin firing in budding yeast. EMBO J. 30(23):4805-4814. doi:10.1038/emboj.2011.404

Miyazawa-Onami M, Araki H, Tanaka S. 2017. Pre-initiation complex assembly functions as a molecular switch that splits the mcm2-7 double hexamer. EMBO Rep. 18(10):17521761. doi:10.15252/embr.201744206

Mu R, Tat J, Zamudio R, Zhang Y, Yates JR, 3rd, Kumagai A, Dunphy WG, Reed SI. 2017. Cks proteins promote checkpoint recovery by stimulating phosphorylation of treslin. Mol Cell Biol. 37(20) doi:10.1128/MCB.00344-17

Muramatsu S, Hirai K, Tak YS, Kamimura Y, Araki H. 2010. Cdk-dependent complex formation between replication proteins $\mathrm{dpb} 11$, sld2, pol (epsilon\}, and gins in budding yeast. Genes Dev. 24(6):602-612. doi:10.1101/gad.1883410

Notredame C, Higgins DG, Heringa J. 2000. T-coffee: A novel method for fast and accurate multiple sequence alignment. J Mol Biol. 302(1):205-217. doi:10.1006/jmbi.2000.4042 S0022-2836(00)94042-7

Petryk N, Kahli M, d'Aubenton-Carafa Y, Jaszczyszyn Y, Shen Y, Silvain M, Thermes C, Chen CL, Hyrien O. 2016. Replication landscape of the human genome. Nat Commun. 7:10208. doi:10.1038/ncomms10208

Ponting CP, Schultz J, Copley RR, Andrade MA, Bork P. 2000. Evolution of domain families. Adv Protein Chem. 54:185-244. doi:10.1016/s0065-3233(00)54007-8

Remus D, Beuron F, Tolun G, Griffith JD, Morris EP, Diffley JFX. 2009. Concerted loading of mcm2-7 double hexamers around DNA during DNA replication origin licensing. Cell. 139(4):719-730. doi:10.1016/j.cell.2009.10.015

Reusswig KU, Zimmermann F, Galanti L, Pfander B. 2016. Robust replication control is generated by temporal gaps between licensing and firing phases and depends on degradation of firing factor sld2. Cell Rep. 17(2):556-569. doi:10.1016/j.celrep.2016.09.013

Ryba T, Hiratani I, Lu J, Itoh M, Kulik M, Zhang J, Schulz TC, Robins AJ, Dalton S, Gilbert DM. 2010. Evolutionarily conserved replication timing profiles predict long-range chromatin interactions and distinguish closely related cell types. Genome Res. 20(6):761-770. doi:10.1101/gr.099655.109

Sanchez-Pulido L, Diffley JFX, Ponting CP. 2010. Homology explains the functional similarities of treslin/ticrr and sld3. Curr Biol. 20(12):R509-510. doi:10.1016/j.cub.2010.05.021

Sansam CG, Pietrzak K, Majchrzycka B, Kerlin MA, Chen J, Rankin S, Sansam CL. 2018. A mechanism for epigenetic control of DNA replication. Genes Dev. 32(3-4):224-229. doi:10.1101/gad.306464.117 
664

665

666

667

668

669

670

671

672

673

674

675

676

677

678

679

680

681

682

683

684

685

686

687

688

689

690

691

692

693

694

695

696

697

698

699

700

701

702

703

704

705

706

707

708

709

710

Sansam CL, Cruz NM, Danielian PS, Amsterdam A, Lau ML, Hopkins N, Lees JA. 2010. A vertebrate gene, ticrr, is an essential checkpoint and replication regulator. Genes Dev. 24(2):183-194. doi:10.1101/gad.1860310

Soding J, Biegert A, Lupas AN. 2005. The hhpred interactive server for protein homology detection and structure prediction. Nucleic Acids Res. 33(Web Server issue):W244248. doi:10.1093/nar/gki408

Sonnhammer EL, Hollich V. 2005. Scoredist: A simple and robust protein sequence distance estimator. BMC Bioinformatics. 6:108. doi:10.1186/1471-2105-6-108

Tanaka S, Araki H. 2011. Multiple regulatory mechanisms to inhibit untimely initiation of DNA replication are important for stable genome maintenance. PLoS Genet. 7(6):e1002136. doi:10.1371/journal.pgen.1002136

Tanaka S, Nakato R, Katou Y, Shirahige K, Araki H. 2011. Origin association of sld3, sld7, and cdc45 proteins is a key step for determination of origin-firing timing. Curr Biol. 21(24):2055-2063. doi:10.1016/j.cub.2011.11.038

Tanaka S, Umemori T, Hirai K, Muramatsu S, Kamimura Y, Araki H. 2007. Cdk-dependent phosphorylation of sld2 and sld3 initiates DNA replication in budding yeast. Nature. 445(7125):328-332. doi:10.1038/nature05465

Vangone A, Spinelli R, Scarano V, Cavallo L, Oliva R. 2011. Cocomaps: A web application to analyze and visualize contacts at the interface of biomolecular complexes. Bioinformatics. 27(20):2915-2916. doi:10.1093/bioinformatics/btr484

Walker JR, Corpina RA, Goldberg J. 2001. Structure of the ku heterodimer bound to DNA and its implications for double-strand break repair. Nature. 412(6847):607-614. doi:10.1038/35088000

Wang S, Sun S, Li Z, Zhang R, Xu J. 2017. Accurate de novo prediction of protein contact map by ultra-deep learning model. PLoS Comput Biol. 13(1):e1005324. doi:10.1371/journal.pcbi.1005324

Whittaker CA, Hynes RO. 2002. Distribution and evolution of von willebrand/integrin a domains: Widely dispersed domains with roles in cell adhesion and elsewhere. Mol Biol Cell. 13(10):3369-3387. doi:10.1091/mbc.e02-05-0259

Wu CH, Apweiler R, Bairoch A, Natale DA, Barker WC, Boeckmann B, Ferro S, Gasteiger E, Huang $\mathrm{H}$, Lopez $\mathrm{R}$, et al. 2006. The universal protein resource (uniprot): An expanding universe of protein information. Nucleic Acids Res. 34(Database issue):D187-191. doi:10.1093/nar/gkj161

Yang J, Zhang Y. 2015. I-tasser server: New development for protein structure and function predictions. Nucleic Acids Res. 43(W1):W174-181. doi:10.1093/nar/gkv342

Yeeles JT, Deegan TD, Janska A, Early A, Diffley JF. 2015. Regulated eukaryotic DNA replication origin firing with purified proteins. Nature. 519(7544):431-435. doi:10.1038/nature14285

Yeeles JT, Janska A, Early A, Diffley JF. 2017. How the eukaryotic replisome achieves rapid and efficient DNA replication. Mol Cell. 65(1):105-116. doi:10.1016/j.molcel.2016.11.017

Zegerman P. 2015. Evolutionary conservation of the cdk targets in eukaryotic DNA replication initiation. Chromosoma. 124(3):309-321. doi:10.1007/s00412-014-0500-y

Zegerman P, Diffley JFX. 2007. Phosphorylation of sld2 and sld3 by cyclin-dependent kinases promotes DNA replication in budding yeast. Nature. 445(7125):281-285. doi:10.1038/nature05432

Zegerman P, Diffley JFX. 2010. Checkpoint-dependent inhibition of DNA replication initiation by sld3 and dbf4 phosphorylation. Nature. 467(7314):474-478. doi:1038/nature09373 
bioRxiv preprint doi: https://doi.org/10.1101/2021.07.24.453613; this version posted July 24, 2021. The copyright holder for this preprint

(which was not certified by peer review) is the author/funder, who has granted bioRxiv a license to display the preprint in perpetuity. It is made available under aCC-BY-NC 4.0 International license.

711 Zou L, Stillman B. 1998. Formation of a preinitiation complex by s-phase cyclin cdk-dependent loading of cdc45p onto chromatin. Science. 280(5363):593-596. 
Figure legends

715

716

Figure 1 - Treslin/TICRR domain structure

717 CIT: Conserved in Treslins; M: middle domain; STD: SId3-Treslin domain; TDIN: TopBP1/Dpb11

718 interaction domain. Numbers indicate amino acid position in human Treslin/TICRR or budding

719 yeast Sld3. Arrows point to interacting proteins. 2xP; two phospho-serines.

720

721 Figure 2 - The STD domain of Treslin/TICRR is required for DNA replication in cultured

722 human cells

723 (A) Whole cell lysates of stable U2OS cell lines carrying siRNA resistant transgenes of

724 Treslin/TICRR-WT, Treslin/TICRR-2PM (threonine 969 and serine 1001 double alanine mutant that cannot interact with TopBP1(Boos et al 2011)) or three clones of Treslin/TICRR with a deletion of the STD (amino acids 717-792 deleted) were immunoblotted with rabbit antiTreslin/TICRR (amino acids 1566-1909) antibodies. Ponceau (Ponc.) staining controlled for loading (Load.).

(B) Cells described in A were treated with control or Treslin/TICRR siRNAs (siCtr/siTres) before analysis by flow cytometry detecting BrdU (5-bromo-2'-deoxyuridine; logarithmic (log.) scale) and PI (propidium iodide; linear (lin.) scale). Density plots are shown. Dashed lines indicating peak level of maximal BrdU incorporation in each cell line upon siCtr-treatment allow visual comparison with level upon siTres treatment.

734 (C) Quantification of relative overall DNA replication in cells described in A based on flow cytometry experiments described in B. Averages of BrdU-replication signals of two (all lines were normalised to replication signals of the same cell line upon siCtr-treatments. 
(D) Stable U2OS cell lines expressing siTreslin-resistant Treslin/TICRR- $\triangle$ STD, WT or 2PM were

released from a double thymidine arrest before treatment with siTreslin and nocodazole.

After nocodazole-release for $4 \mathrm{~h}$ or $12 \mathrm{~h}$ cells chromatin was isolated for immunoblotting with

(Coom.) staining of low molecular weight part including histones controlled for loading. Clone

Treslin- $\Delta$ STD -11 was used.

Figure 3 - Treslin/TICRR, SId3 and SId7 contain a Ku70/80-like $\beta$-barrel that are required for

\section{Treslin/SId3-MTBP/SId7 dimerization}

(A) Representative multiple sequence alignment of Ku70-like $\beta$-barrel domain in the

Treslin/TICRR family. The alignment generated with the program T-Coffee (Notredame et al protein sequences included in the alignment are indicated by flanking residue positions.

757 family, shown in the first lane; this prediction is consistent with the secondary structure of

758 Ku70-like $\beta$-barrel domains, shown below each of the proteins with known structure (Ku70, PDB:5Y58E; Ku80, PDB:5Y58F; SPOC, PDB:10W1A; Sld7, PDB:3X37B; Sld3, PDB:3X37A). Alpha- 
762 (which are correlated with amino acid conservation) of each alignment column: black (>3),

763 grey (between 3 and 1.5) and light grey (between 1.5 and 0.5) (Sonnhammer \& Hollich 2005).

764 Sequences are named according to their specie common name or abbreviation corresponding

765 as follow to their UniProt identification and specie name (Wu et al 2006):Human,

766 Q7Z2Z1_HUMAN, Homo sapiens; Mouse, Q8BQ33_MOUSE, Mus musculus; Sarha,

767 G3WMD4_SARHA; Sarcophilus harrisii; Chicken, E1BU88_CHICK; Gallus gallus; Frog,

768 D3IUT5_XENLA, Xenopus laevis; Latch, H3BCK8_LATCH, Latimeria chalumnae; Tetng,

769 H3CYF8_TETNG, Tetraodon nigroviridis; Collu, AOA4U5UGV6_COLLU, Collichthys lucidus;

770 Lepoc, W5ND48_LEPOC, Lepisosteus oculatus; 9tele, A0A3B3T1X9_9TELE, Paramormyrops

771 kingsleyae; Ictpu, A0A2D0SG01_ICTPU, Ictalurus punctatus; Fish, Q6DRL4_DANRE, Danio

772 rerio. Blue asterisks: amino acid positions in SId3 that mediate Sld7 interaction (Itou et al

773 2015)

774 (B) Schematic representation of Treslin/TICRR mutants (i) used for interaction studies (ii). For

775 (ii), the indicated N-terminally 3HA-tagged Treslin/TICRR fragments were transiently

776 transfected into 293 T cells before immunoprecipitation from cell lysates using control IgG

777 (IgG IP) or rabbit anti-MTBP (amino acids 1-284) (MTBP-IP). Lysates and precipitates were

778 immunoblotted with detection by rat anti-MTBP $(12 \mathrm{H} 7)$ and anti-HA antibodies. VWA: von

779 Willebrand A domain; $\beta$, $\beta$-barrel

780

781 Figure 4 - The CIT and the region between amino acids 1057-1257 of Treslin/TICRR

782

cooperate to support replication in human cells

783 (A) Schematic representation of Treslin/TICRR mutants used in this figure. $\Delta$ : deletion; C99,

784 651, 853: C-terminal 99, 651 or 853 amino acids, Chk1 kinase binding requires the C-terminal

78599 amino acids, BRD2/4 binds to a region between amino acids 1515 and 1600 that were 
deleted in Treslin/TICRR- $\Delta$ C651, $-\Delta$ C853, $-\Delta$ C394 and $-\Delta$ C309 (latter two mutants shown in

787 Fig. S5), respectively. $\Delta \mathrm{CIT}$, amino acids 1-264 deleted.

788 (B) Flow cytometry density plots of experiments as described in Fig. 2B using the stable U2OS

789 cell lines expressing siTreslin-resistant Treslin/TICRR mutants described in A. Cell clones:

$790 \quad \Delta$ C853-5, $\Delta$ CIT(-C-full)-5; $\Delta$ CIT- $\Delta$ C99-25; $\Delta$ CIT- $\Delta$ C651-61; core-35.

791 (C) Quantification of relative overall replication as described in Fig. 2C of several independent

(none; WT), 5 ( $\Delta$ CIT(-C-full); $\Delta$ C853), 3 ( $\Delta$ CIT- $\Delta$ C99; $\Delta$ CIT- $\Delta$ C651; core); significance tests:

(D) Immunoblot with mouse anti-GFP or rat anti-MTBP (12H7) antibodies of co-

immunoprecipitation experiment using 293 T cells transiently transfected with GFP-Flag-

Treslin/TICRR-WT or core. Native lysates were immunoprecipitated with anti-GFP nanobodies

(GFP-IP) or empty control beads (Ctr. IP).

799

800 Figure 5 - Treslin/TICRR-core does not support replisome formation

801 (A) Stable U2OS cell lines expressing no transgene or siTreslin-resistant Treslin/TICRR-WT or

802 core were released from a thymidine arrest before treatment with siTreslin or siCtr and nocodazole. After nocodazole-release for $4 \mathrm{~h}$ or $12 \mathrm{~h}$ cells were analysed by BrdU-PI flow cytometry. Clone Treslin-core-35 was used.

(B) Chromatin of cells treated as described in A was isolated for immunoblotting with rabbit

806 anti-Mcm5, rat anti-Cdc45 and mouse anti-PCNA antibodies. Coomassie (Coom.) staining of

807 low molecular weight part including histones controlled for loading. In the high exposure

808 (exp.) the strongest band is saturated. 
809 (C) Whole cell lysates of cells treated as described in A were immunoblotted using mouse

810 anti-cyclin A antibody.

811

812 Figure 6 - Treslin/TICRR domain structure with described molecular activities

813 The SId3-like core of Treslin/TICRR is formed by the Ku70/80-like $\beta$-barrel, the STD and the

814 TDIN domains (red). All core domains are essential for replication. Two non-core domains, the

815 CIT domain that contains a Ku70/80-like vWA fold and the domain between amino acids 1057

816 and 1257, cooperate to support DNA replication in human cells. Binding regions of described

817 interactors are shown. "?" indicates that undescribed/hypothetical activities may reside in

818 structurally uncharacterised regions of the protein. 


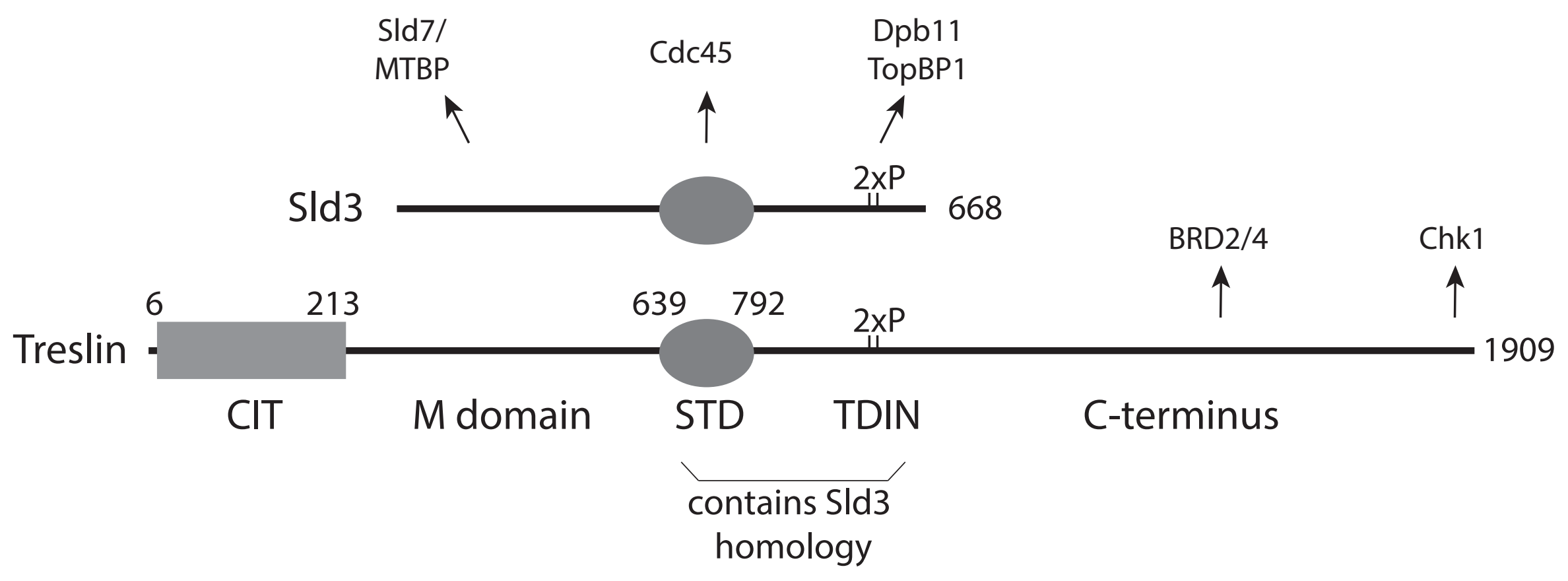



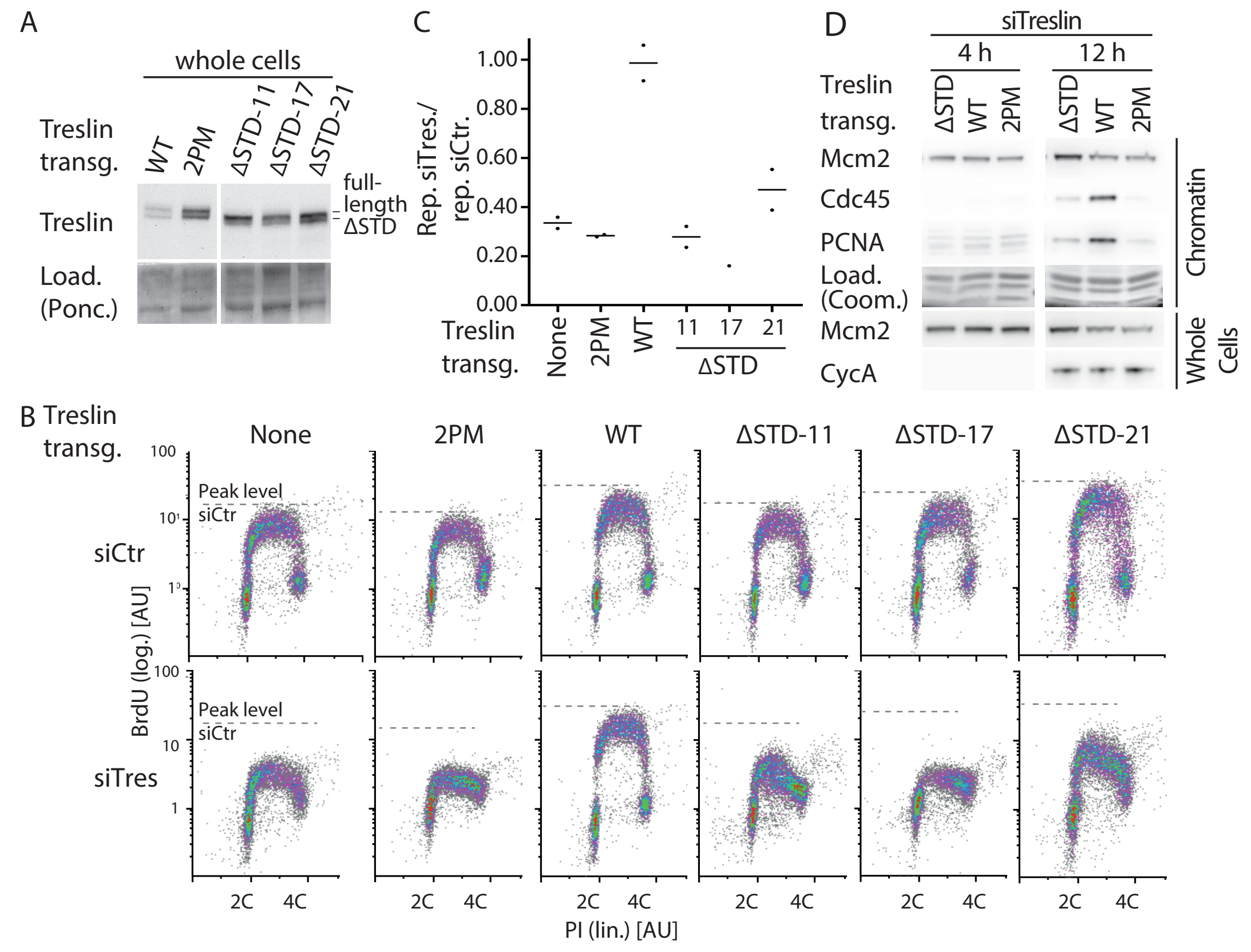
bioRxiv preprint doi: https://doi.org/10.1101/2021.07.24.453613; this version posted July 24, 2021. The copyright holder for this preprint (which was not certified by peer review) is the author/funder, who has granted bioRxiv a license to display the preprint in perpetuity. It is made available under aCC-BY-NC 4.0 International license.

Figure 3

A

\begin{tabular}{|c|c|c|}
\hline Human & & FTOFTWTYT \\
\hline & 301 & $\begin{array}{l}\text { EIQETWTVTLEPLAMHQRHFQK } \\
\text { EIEETWAISLERLAMHQRHFQK . . . }\end{array}$ \\
\hline Sarha & & KIRQTWKVTLEPLAMHQRNFQR. \\
\hline Chicken & 295 & ..KESCAVILERLAMSQRQLHC. . \\
\hline Frog & & KQLDCAVSLEPVSMIQKLSTS. . \\
\hline Latch & & EEQHRCAVTLDPVSCTPRTLLR. \\
\hline Tetng & 266 & . GQRCHVLLEPLCRGQKLLPE. \\
\hline Collu & & TQSCGVMVEPVSRSQRLLPE. \\
\hline & & FPSQTGVLQWGAGKE. \\
\hline 9tele & & .QETCSUTMEPVSAGLHQFSS. \\
\hline Ictpu & 299 & . KQTCSVSLEPVSCRQRRLCG. \\
\hline Fish & 302 & .KRSCNVTLEPVSYRQRRSLRA......... \\
\hline Ku70 & 265 & KGYTMYTHEKAGVRYKLVYEHE. \\
\hline & & LEEEEEEEEEEHHH $\ldots \ldots \ldots \ldots \ldots \ldots$ LEEEEEEEEELLLLLLLLLLEEEEEEEL $\ldots \ldots$ LEEEEEEEEEEEELLLLL $\ldots$ \\
\hline Ku80 & 209 & VRVFSGELRLGADILSTQTSNPSGSMQDENCLCIKVEAFPATKAVSGL.NRKTAVEVEDSQKKERYVGVKSIIEYEIHNEGNKK \\
\hline & & LLLEEEE EEELLLHHHHLLLLLLLHHHLLLLEEEE EEEE ELLLLLLLL. LLLLEEEELLLLLLLEEEELLLLLLEEEEELL. \\
\hline SPOC 3 & & 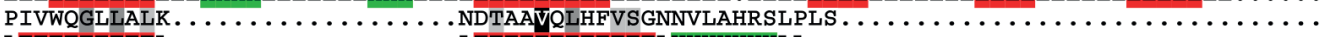 \\
\hline Sld7 & 3 & 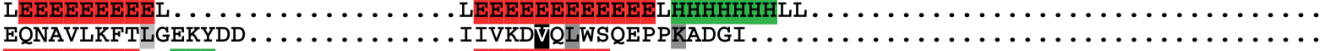 \\
\hline
\end{tabular}

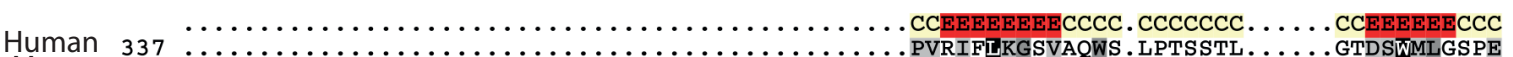

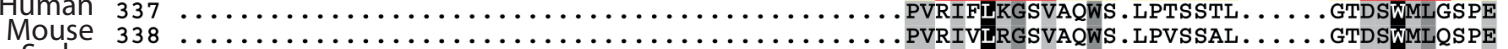

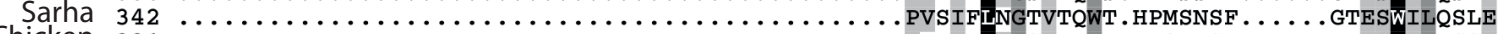

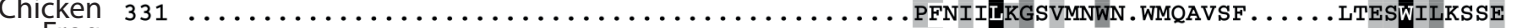

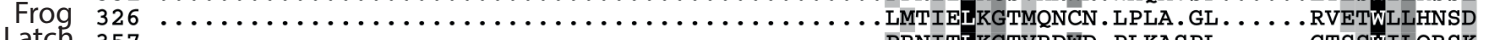

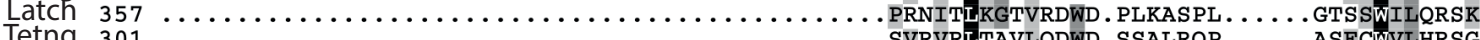

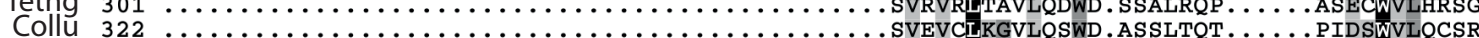

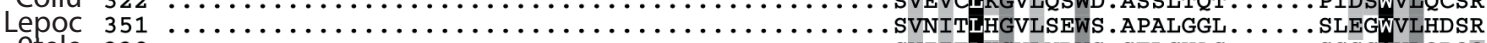

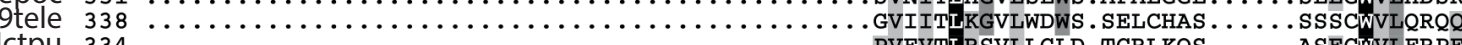

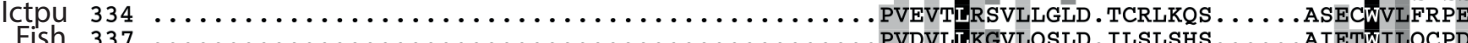

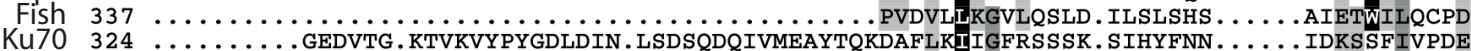

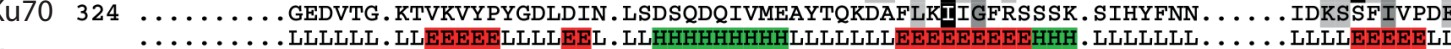
KU80 295 EDDQSGSSYIPVTISKDSVTKAYRYGADYVVLPSVLVDQTVYE. . . SFPGLDLRGFLNREA. . LPRYFL ....... TSESSFITADT

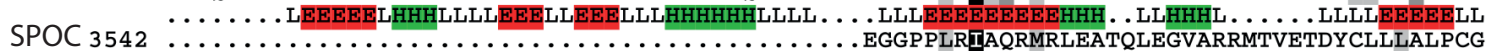

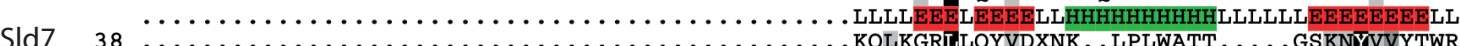

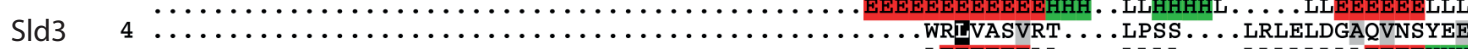
Human 369 EST $\ldots$ HHHHHHHHH.

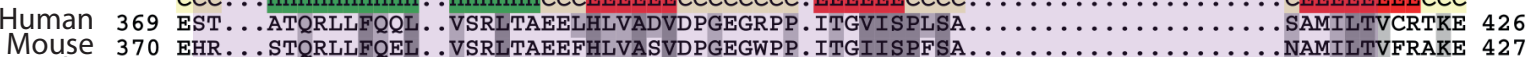

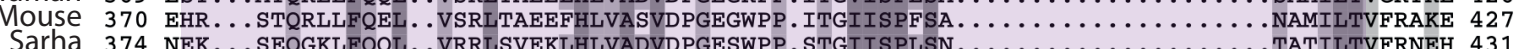

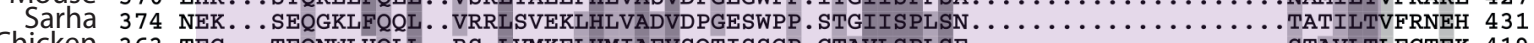

Chicken 363 TEC...TEQNWLHQLI...RS. LVMKELHMIAEVSQTISSCP.CTAVLSPLSE . $\ldots \ldots \ldots \ldots \ldots \ldots \ldots$.

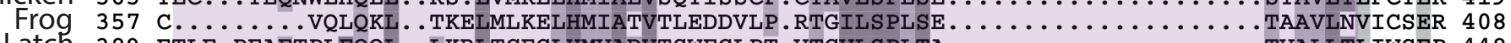
Latch 389 ETLE.PEAETPLFQQL. .LKRLTCEGLHMVADVTSWEGLPT.VIGVLSPLTA. $\ldots \ldots \ldots \ldots \ldots \ldots \ldots$ TVALLTLIWSEP 448

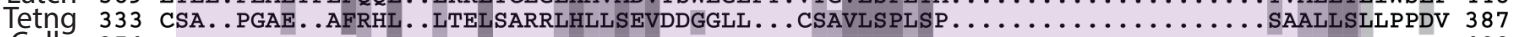

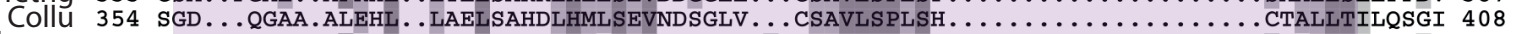

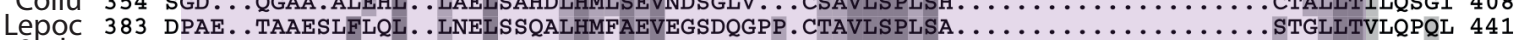
9tele 370 GTAG.DSODGASFLNL.

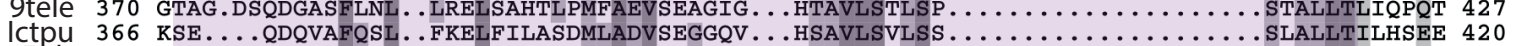

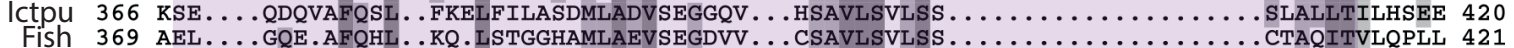

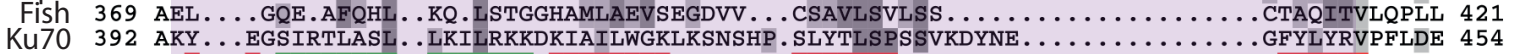

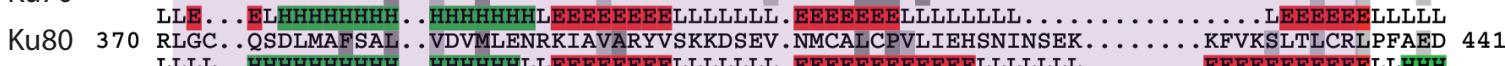

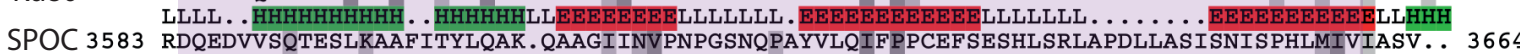
等

SId7 $71 \ldots \ldots$. SSTTSYYFASK..LKNE...NRGIVIDLLNG. TNNNDHLLILHRKLK . $\ldots \ldots \ldots \ldots \ldots \ldots \ldots$ KVQCLKLNLNVK 122

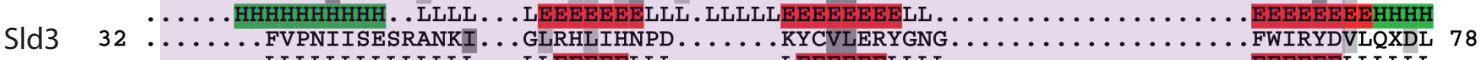

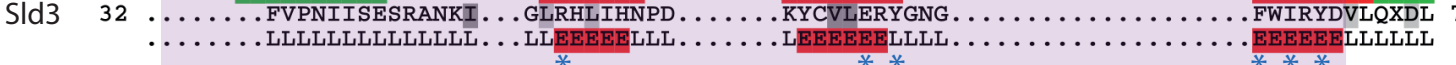
deletion abrogates MTBP binding (see B)

B (i) 6

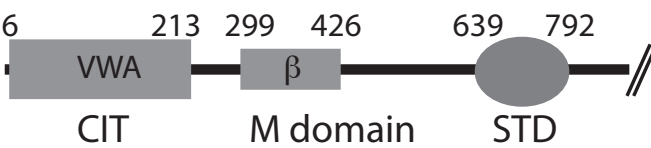

$260-671$

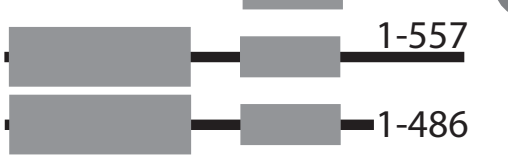

$\Delta 370-400$

$\Delta 401-420$

$\Delta 487-517$

$\Delta 518-530$

$\Delta 531-543$

$\Delta 544-557$

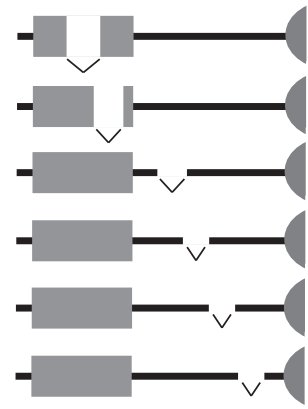

(ii)
IP

$\lg G$

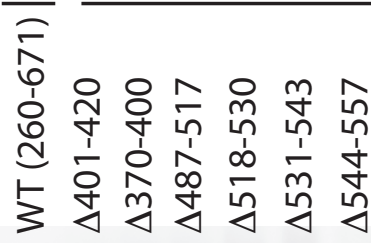

IP

MTBP
MTBP binding

yes

yes

no

no

no

yes

no

no

yes
MTBP

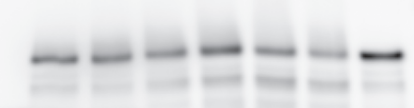

$\mathrm{HA}$
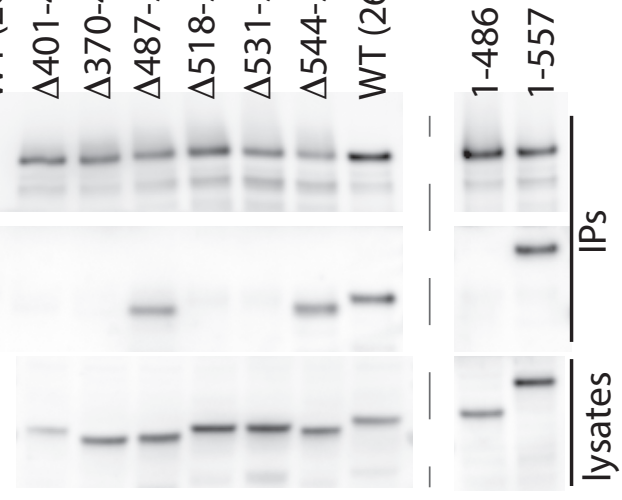
bioRxiv preprint doi: https://doi.org/10.1101/2021.07.24.453613; this version posted July 24, 2021. The copyright holder for this prepr䍏igure 4 (which was not certified by peer review) is the author/funder, who has granted bioRxiv a license to
made available under aCC-BY-NC 4.0 International license.

A

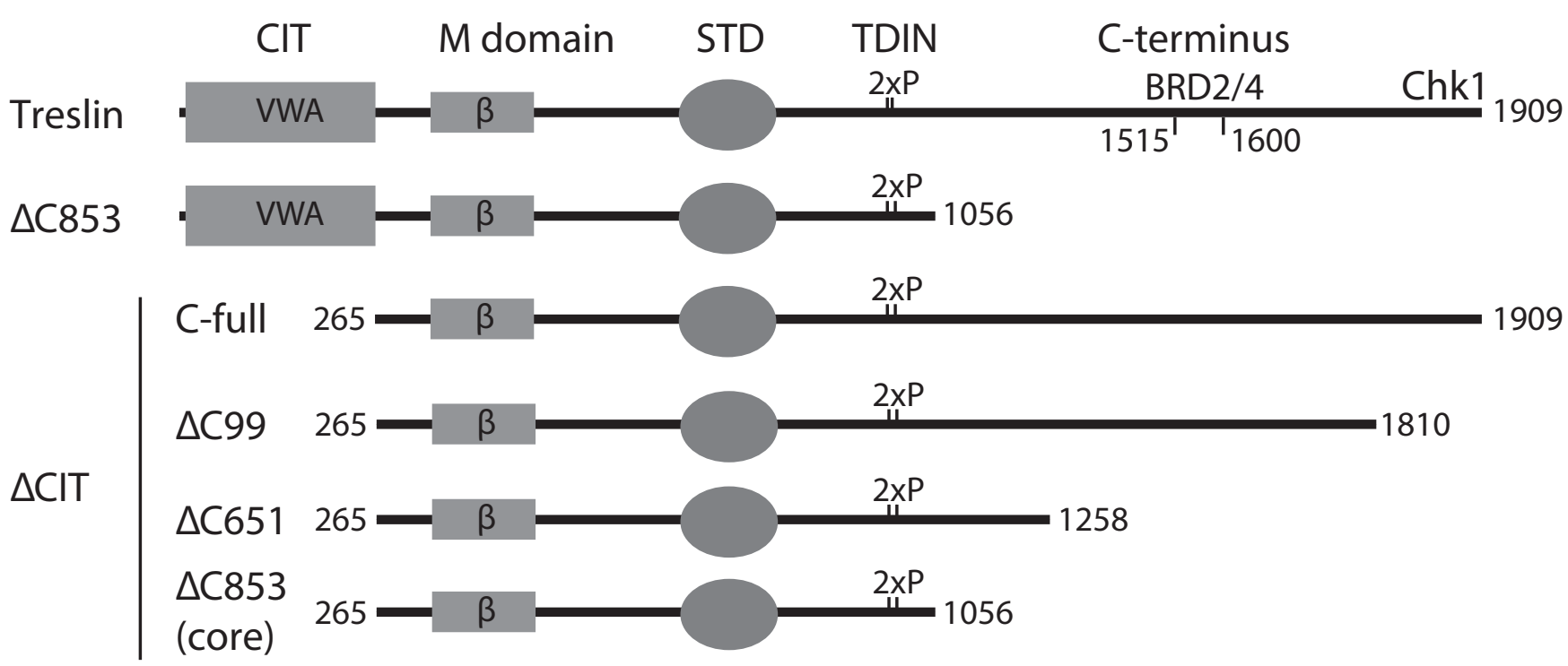

B Treslin transg.

$\Delta C 853$

\begin{tabular}{ccc}
\multicolumn{4}{c}{$\Delta$ CIT } \\
\hline C-full $\Delta$ C99 $\Delta$ C651 Core
\end{tabular}

100

siCtr

Peak level
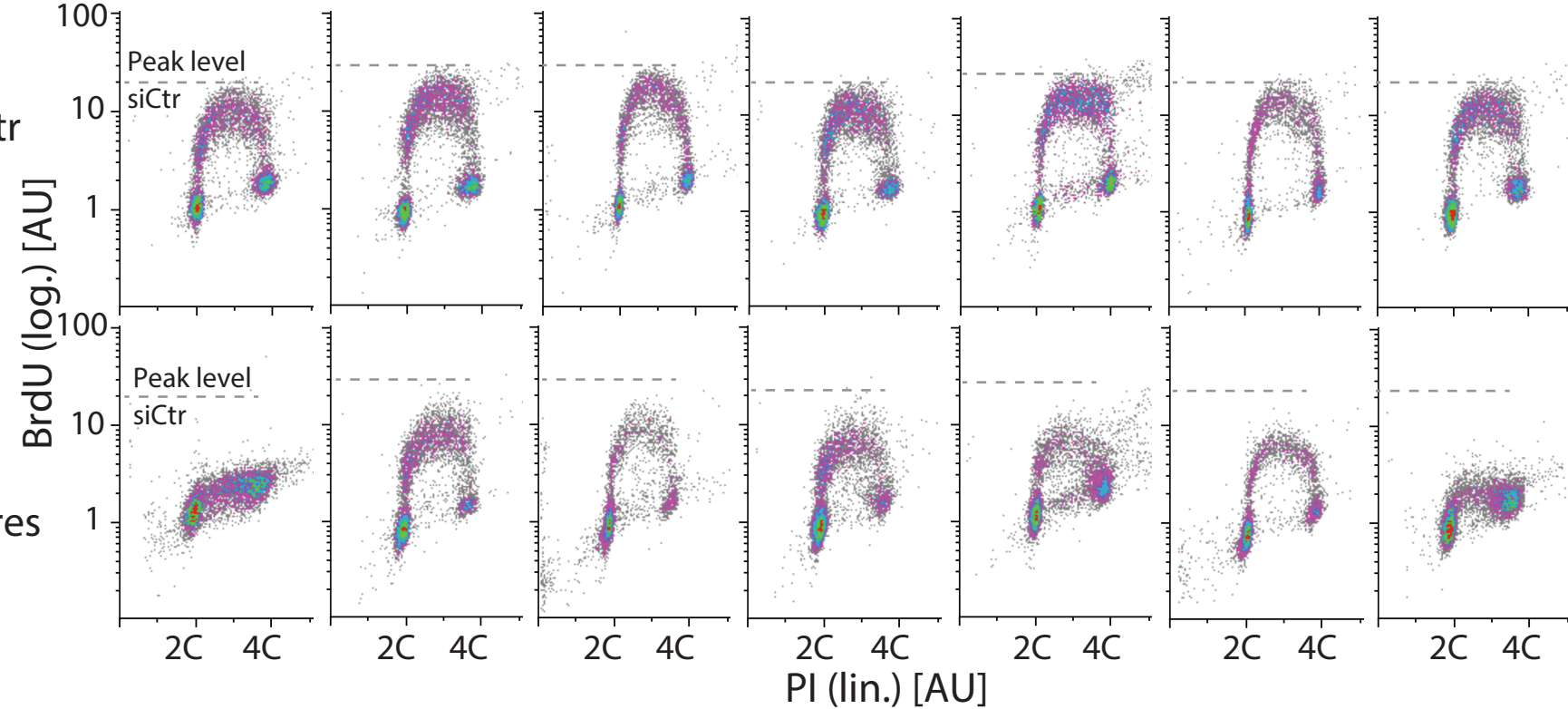

C

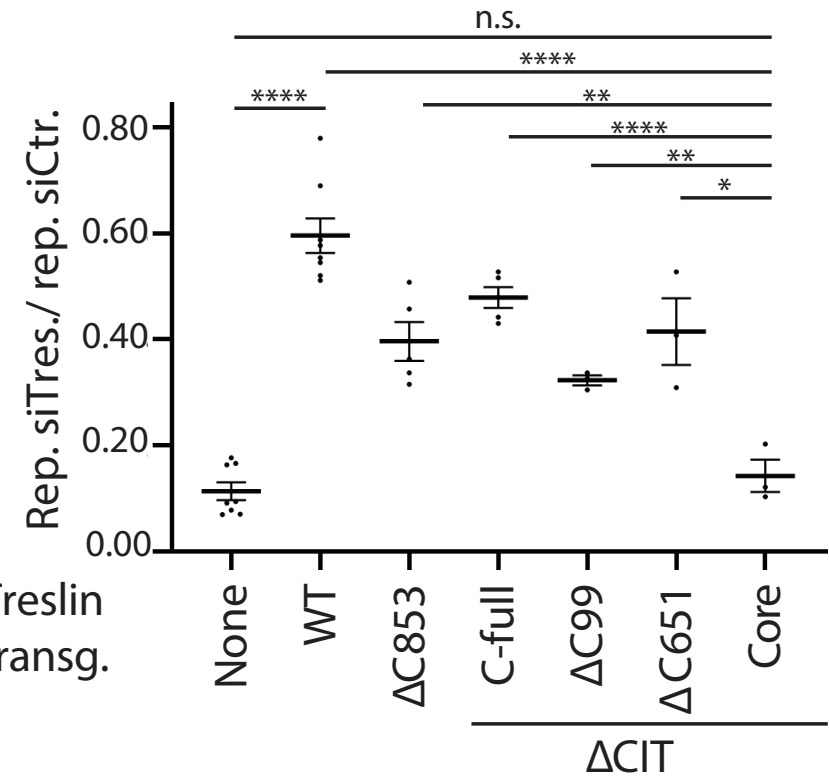

D

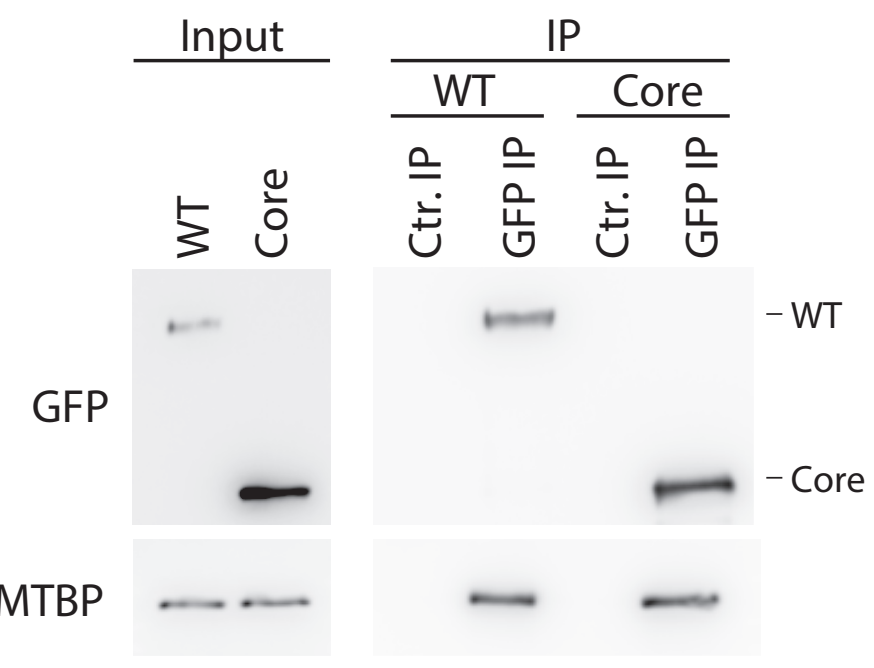


bioRxiv preprint doi: https://doi.org/10.1101/2021.07 24.453613; this version posted July 24, 2021. The copyright holder for this preprint

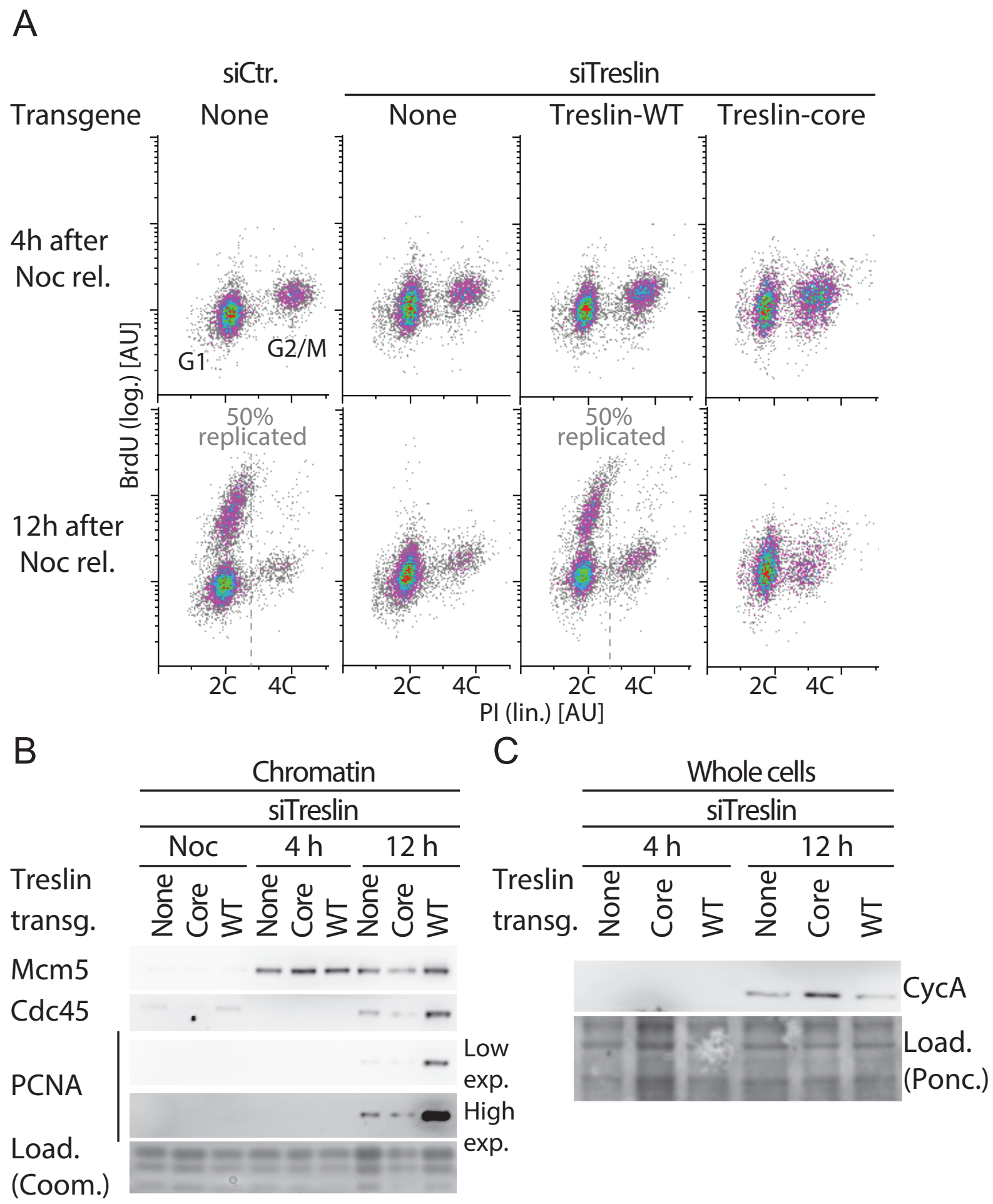




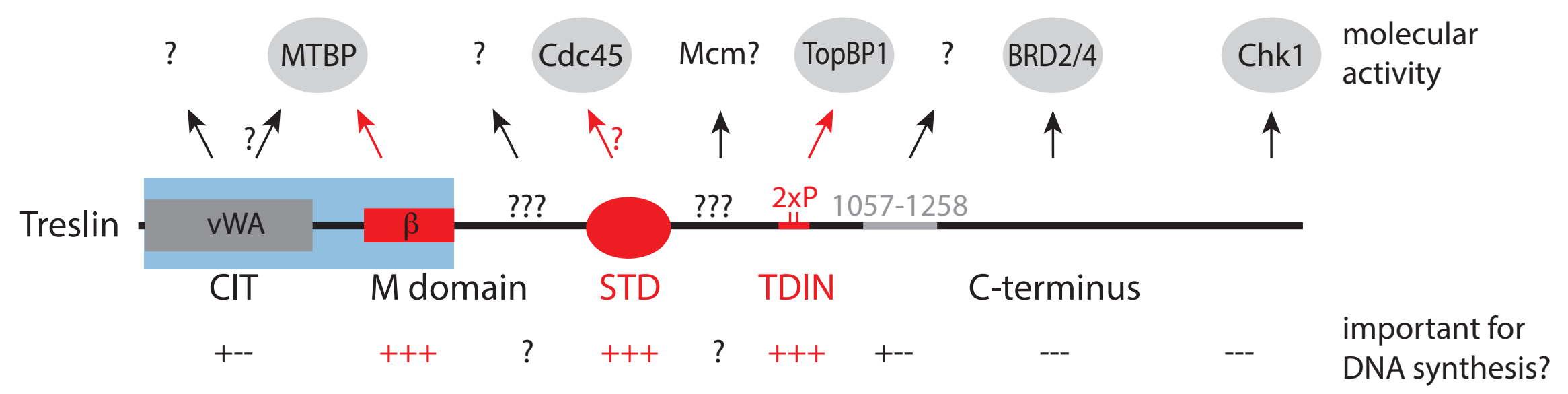

SId3-like core

region inclding Ku70/80 homology 
bioRxiv preprint doi: https://doi org/10.1101/2021.07 24.453613; this version posted July 24, 2021. The copyright holder for this preprint

(which was not certified by peer review) is the author/funder, who has granted bioRxiv a license to display the preprint in perpetuity. It is made available under aCC-BY-NC 4.0 International license.

\section{Supplementary Information}

822 Refining the domain architecture model of the replication origin firing factor Treslin/TICRR

823

824 Pedro Ferreira ${ }^{1 \wedge}$, Luis Sanchez-Pulido ${ }^{2 \wedge}$, Anika Marko $^{1}$, Chris P Ponting $^{2}$, Dominik Boos ${ }^{1 *}$

825

$826{ }^{1}$ Vertebrate DNA Replication Lab, Centre for Medical Biotechnology, University of Duisburg-Essen, 45141 Essen,

827 Germany

$828{ }^{2}$ Medical Research Council Human Genetics Unit, IGMM, University of Edinburgh, Edinburgh EH9 3JR,

829 Scotland, UK

830 equal contribution

$831{ }^{*}$ corresponding author: dominik.boos@uni-due.de; phone: +49 201183 4132, ORCID: https://orcid.org/0000-

$832 \underline{0003-0018-4375}$

833 
Supplementary figure S1 - Treslin/TICRR- $\triangle$ STD is proficient in binding TopBP1

GFP-Flag-Treslin/TICRR-WT, 2PM or $\triangle$ STD were transiently transfected into 293T cells. Native lysates were used for anti-GFP nanobody immunoprecipitation (IP) in the presence of recombinant Cdk2-cyclin A to promote interaction with TopBP1. Lysates and bead-bound material were analysed by immunoblotting using mouse anti-GFP and rabbit anti-antibodies. Treslin/TICRR-2PM did not bind TopBP1, as expected because the relevant CDK sites in the TDIN are mutated to alanine. Treslin/TICRR- $\triangle$ STD was able to bind to TopBP1.

\section{Supplementary figure S2 - The CIT domain of Treslin/TICRR contains a vWA fold}

845 Representative multiple sequence alignment of VWA domain in Treslin family. Secondary structure prediction using PsiPred was performed for the Treslin family, shown in the first lane; this prediction is consistent with the secondary structure of VWA domains, shown below each of the selected proteins with known structure (CFB, PDB:3HRZD; Sec23, PDB:2NUTA; Ku70, PDB:5Y58E). For figure methods and abbreviations see Figure $2 \mathrm{~A}$ legend.

Supplementary figure S3 - Coevolution-based and known contact maps of Ku70-like $\beta$ barrel domains.

RaptorX coevolution-based contact prediction for Treslin (Q7Z2Z1_HUMAN, residues 290 to 460) and known contact maps for Ku70, Ku80, SPOC, SId7, and SId3. Contact maps of Ku70like $\beta$ barrel domains whose structures are known were generated using the Cocomaps server (cut-off distance value $=7$ Ångstroms) (Vangone et al 2011) are shown. Beta-strands are labelled 1 to 7 and coloured in red, orange, yellow, green, cyan, violet, and purple, respectively. B-strand contact pairs are labelled.

859 Structural comparison with DALI using as input the Ku70 $\beta$-barrel domain core found a diverse 860 set of proteins (Holm \& Laakso 2016). This includes yeast Ku80 and human Ku70/Ku80 orthologs (XRCC5 and XRCC6) (Chen et al 2018, Nemoz et al 2018, Walker et al 2001). Other

862 known similar structure were identified (DALI Z-Score > 7.5): the human transcriptional corepressor SHARP SPOC domain (PDB-ID: 10W1_A) (Ariyoshi \& Schwabe 2003), fission yeast 
subunit of the Mediator complex (Eletsky et al 2011, Milbradt et al 2011, Vojnic et al 2011). Med25 ACID domains were recently characterised in interaction with unfolded acidic transactivation domains (TADs) (Landrieu et al 2015, Lee et al 2018) and are able to have allosteric communication between opposite $\beta$-barrel's binding surfaces (Henderson et al 2018). Therefore Ku70-like $\beta$-barrel domains have been described with roles related to dimerisation, protein-protein and protein-DNA interaction.

872

Supplementary figure S4 - Analysis of several stable U2OS clones expressing Treslin/TICRR$\Delta \mathrm{CIT}$ or various $\mathrm{C}$-terminal truncation mutants.

A) Schematic giving an overview over the Treslin/TICRR mutants used in this figure. B-D) Immunoblots (i) to assess transgene expression levels and BrdU-flow cytometry (ii) to determine overall DNA replication of the indicated Treslin/TICRR mutants shown in A. The following U2OS clones were used for main Fig. 4: Treslin/TICRR- $\Delta C$ IT-5, $\Delta$ C853-5. Immunoblots of whole cell lysates used mouse anti-GFP and Ponceau staining (as a loading control). Flow cytometry was done after replacing endogenous Treslin/TICRR against the indicated siRNA-resistant transgenes using RNAi. Density plots are shown. Parental U2OS cells and a line expressing Treslin/TICRR-WT served to control the experiment. Dashed lines show BrdU peak level of the respective control siRNA-treated cell line in the same experiment. Clones were picked that expressed the Treslin/TICRR transgenes at similar or higher levels than Treslin/TICRR-WT to avoid under-estimating the capability of the mutants to support replication. For Treslin/TICRR- $\Delta$ C651, only low-expressing clones were found. The results are still conclusive, though, because all clones were capable to support replication.

E) Quantification of overall replication in mutant Treslin/TICRR U2OS cell lines described in A-

D, based on BrdU-PI flow cytometry experiments as described in B-D. For comparison, the shortest C-terminal deletion mutant $(\Delta 99)$ is shown in addition to the usual control lines. The quantifications indicate that all mutants were active. It also shows the clonal variability that did not clearly correlate with expression levels, as indicated by the Treslin/TICRR- $\Delta$ C651 clones 1-3. 
897 A) Schematic giving an overview over the Treslin/TICRR mutants used in B-E

898 B-D) Immunoblots (i) and BrdU-Flow cytometry (ii) of stable U2OS cell lines expressing 899 indicated Treslin/TICRR-mutants shown in A. Immunoblots of whole cell lysates using mouse 900 anti-GFP and Ponceau staining (as a loading control) served to assess transgene expression

901 levels relative to each other and Treslin/TICRR-WT. The following U2OS clones were used for 902 main figures: Treslin/TICRR- $\Delta$ CIT/ $\Delta$ C651-61 (Fig. 4), core-35 (Fig. 4, 5). Clones were picked 903 that expressed the Treslin/TICRR transgenes at similar or higher levels than Treslin/TICRR-WT

904 to avoid under-estimating the capability of the mutants to support replication. For BrdU-flow 905 cytometry, density plots show overall DNA replication of stable U2OS clones shown in A. Flow cytometry was done after replacing endogenous Treslin/TICRR against the indicated siRNAresistant transgenes using RNAi. Parental U2OS cells and a line expressing Treslin/TICRR-WT served to control the experiment. Dashed lines show BrdU peak level of the respective control siRNA-treated cell line in the same experiment.

910 E) Quantification of overall replication in mutant Treslin/TICRR U2OS cell lines described in A, 911 based on BrdU-PI flow cytometry experiments as described in B. For comparison,

912 Treslin/TICRR- $\Delta$ CIT containing the full C-terminus and Treslin/TICRR-core are shown in 913 addition to the usual control lines. Treslin/TICRR- $\Delta C I T / \Delta C 651$ supports replication to levels 914 comparable with Treslin/TICRR- $\Delta$ CIT. The exact level of replication depended on the clone 915 used. No Treslin/TICRR- $\Delta \mathrm{CIT} / \Delta \mathrm{C651}$ clone, however, supported replication as poorly as 916 Treslin/TICRR-core that showed replication similar to control U2OS cells not expressing a 917 siRNA-resistant transgene.

919 Supplementary figure S6 - Analysis of several stable U2OS clones expressing various C920 terminal truncations in combination with deletion of the CIT or Treslin/TICRR- $\Delta$ C99

921 A) Schematic giving an overview over the Treslin/TICRR mutants used in B-E

922 B) Immunoblots to assess transgene expression levels of stable U2OS clones expressing 923 Treslin/TICRR- $\Delta \mathrm{CIT} / \Delta \mathrm{C} 651$ and $\Delta \mathrm{CIT} / \Delta \mathrm{C} 853$. Immunoblots of whole cell lysates used mouse 924 anti-GFP and Ponceau staining (as a loading control). Clones were picked that expressed the 925 Treslin/TICRR transgenes at similar or higher levels than Treslin/TICRR-WT to avoid under926 estimating the capability of the mutants to support replication. 
927 C/D) Density plots of BrdU-flow cytometry to determine overall DNA replication of stable

928 U2OS clones described in A and B. Flow cytometry was done after replacing endogenous

929 Treslin/TICRR against the indicated siRNA-resistant transgenes using RNAi. Parental U2OS

930 cells and a line expressing Treslin/TICRR-WT served to control the experiment. Dashed lines

931 show BrdU peak level of the respective control siRNA-treated cell line in the same experiment.

932 E) Quantification of overall replication in mutant Treslin/TICRR U2OS cell lines described in A,

933 based on BrdU-PI flow cytometry experiments as described in B. For comparison,

934 Treslin/TICRR- $\Delta$ CIT containing the full C-terminus, Treslin/TICRR- $\Delta C I T / \Delta 651$ and

935 Treslin/TICRR-core are shown in addition to the usual control lines. Treslin/TICRR- $\Delta$ C99

936 supports replication to similar levels as Treslin/TICRR-WT. Treslin/TICRR- $\Delta C I T / \Delta C 99$ supports

937 replication to levels comparable with Treslin/TICRR- $\Delta \mathrm{CIT}$ and $\Delta \mathrm{CIT} / \Delta \mathrm{C} 651$, but much better

938 than Treslin/TICRR-core. Also here, the exact level of replication depended on the clone used.

940 Supplementary figure S7 - Treslin/TICRR-core is proficient in binding MTBP and TopBP1

941 The indicated GFP-Flag-Treslin/TICRR mutants were transiently transfected into 293T cells

942 together with MTBP. Native lysates were used for anti-GFP nanobody immunoprecipitation

943 (IP) in the presence of recombinant Cdk2-cyclin A to promote interaction with TopBP1.

944 Lysates and bead-bound material were analysed by immunoblotting using mouse anti-GFP,

945 rabbit anti-TopBP1 and rat anti-MTBP antibodies. Controls for IP specificity were made:

946 Treslin/TICRR- $\Delta M 1$ and $\triangle M 2$ show decreased (M1) or absent (M2) MTBP signals, as expected.

947 Treslin/TICRR-2PM did not bind TopBP1, as expected because the relevant CDK sites in the

948 TDIN are mutated to alanine. IP capabilities using (near) full-length Treslin/TICRR versions are

949 hard to compare by immunoblotting with those containing larger deletions because of the

950 often weak blotting efficiency of the $210 \mathrm{kD}$ full-length Treslin/TICRR. However, the smaller

951 C-terminal truncations are better comparable. Treslin/TICRR- $\Delta$ C853 and $\Delta 651$ bound similar

952 amounts of TopBP1 and MTBP, whether they contained CIT or not. In some experiments,

953 however, deletion of the CIT seemed to have a minor effect on the amount of MTBP bound 954 (Fig 4D).

955

956 
958

959

960

961

962

963

964

965

966

967

968

969

970

971

972

973

974

975

976

977

978

979

980

981

982

983

984

985

986

987

988

989

990

991

992

993

994

995

996

997

998

999

1000

1001

1002

1003

1004

Ariyoshi M, Schwabe JW. 2003. A conserved structural motif reveals the essential transcriptional repression function of spen proteins and their role in developmental signaling. Genes Dev. 17(15):1909-1920. doi:10.1101/gad.266203

Chen H, Xue J, Churikov D, Hass EP, Shi S, Lemon LD, Luciano P, Bertuch AA, Zappulla DC, Geli $\mathrm{V}$, et al. 2018. Structural insights into yeast telomerase recruitment to telomeres. Cell. 172(1-2):331-343 e313. doi:10.1016/j.cell.2017.12.008

Eletsky A, Ruyechan WT, Xiao R, Acton TB, Montelione GT, Szyperski T. 2011. Solution nmr structure of med25(391-543) comprising the activator-interacting domain (acid) of human mediator subunit 25. J Struct Funct Genomics. 12(3):159-166. doi:10.1007/s10969-011-9115-1

Henderson AR, Henley MJ, Foster NJ, Peiffer AL, Beyersdorf MS, Stanford KD, Sturlis SM, Linhares BM, Hill ZB, Wells JA, et al. 2018. Conservation of coactivator engagement mechanism enables small-molecule allosteric modulators. Proc Natl Acad Sci U S A. 115(36):8960-8965. doi:10.1073/pnas.1806202115

Holm L, Laakso LM. 2016. Dali server update. Nucleic Acids Res. 44(W1):W351-355. doi:10.1093/nar/gkw357

Landrieu I, Verger A, Baert JL, Rucktooa P, Cantrelle FX, Dewitte F, Ferreira E, Lens Z, Villeret V, Monte D. 2015. Characterization of erm transactivation domain binding to the acid/ptov domain of the mediator subunit med25. Nucleic Acids Res. 43(14):71107121. doi:10.1093/nar/gkv650

Lee MS, Lim K, Lee MK, Chi SW. 2018. Structural basis for the interaction between p53 transactivation domain and the mediator subunit med25. Molecules. 23(10) doi:10.3390/molecules23102726

Milbradt AG, Kulkarni M, Yi T, Takeuchi K, Sun ZY, Luna RE, Selenko P, Naar AM, Wagner G. 2011. Structure of the vp16 transactivator target in the mediator. Nat Struct Mol Biol. 18(4):410-415. doi:10.1038/nsmb.1999

Nemoz C, Ropars V, Frit P, Gontier A, Drevet P, Yu J, Guerois R, Pitois A, Comte A, Delteil C, et al. 2018. XIf and aplf bind ku80 at two remote sites to ensure DNA repair by nonhomologous end joining. Nat Struct Mol Biol. 25(10):971-980. doi:10.1038/s41594018-0133-6

Schalch T, Job G, Shanker S, Partridge JF, Joshua-Tor L. 2011. The chp1-tas3 core is a multifunctional platform critical for gene silencing by rits. Nat Struct Mol Biol. 18(12):1351-1357. doi:10.1038/nsmb.2151

Vangone A, Spinelli R, Scarano V, Cavallo L, Oliva R. 2011. Cocomaps: A web application to analyze and visualize contacts at the interface of biomolecular complexes. Bioinformatics. 27(20):2915-2916. doi:10.1093/bioinformatics/btr484

Vojnic E, Mourao A, Seizl M, Simon B, Wenzeck L, Lariviere L, Baumli S, Baumgart K, Meisterernst $M$, Sattler M, et al. 2011. Structure and vp16 binding of the mediator med25 activator interaction domain. Nat Struct Mol Biol. 18(4):404-409. doi:10.1038/nsmb.1997

Walker JR, Corpina RA, Goldberg J. 2001. Structure of the ku heterodimer bound to DNA and its implications for double-strand break repair. Nature. 412(6847):607-614. doi:10.1038/35088000

Zhang Y, Rataj K, Simpson GG, Tong L. 2016. Crystal structure of the spoc domain of the arabidopsis flowering regulator fpa. PLoS One. 11(8):e0160694. doi:10.1371/journal.pone.0160694 
bioRxiv preprint doi: https://doi.org/10.1101/2021.07.24.453613; this version posted July 24, 2021. The copyright holder for this preprint (which was not certified by peer review) is the author/funder, who has granted bioRxiv a license to display the preprint in perpetuity. It is made available under aCC-BY-NC 4.0 International license.

Figure S1

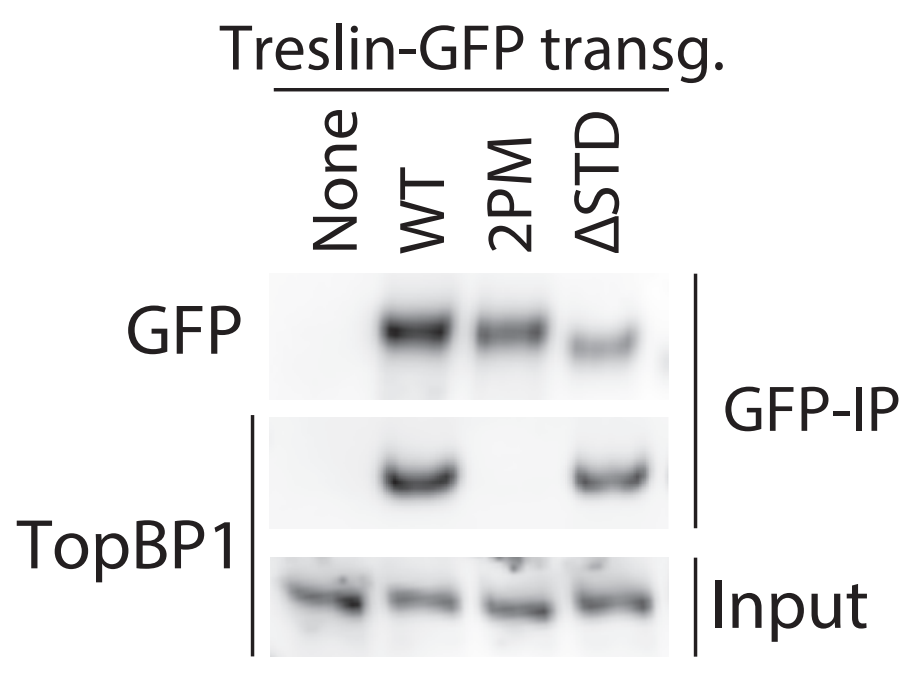


bioRxiv preprint doi: https://doi.org/10.1101/2021.07.24.453613; this version posted July 24, 2021. The copyright holder for this preprint (which was not certified by peer review) is the author/funder, who has granted bioRxiv a license to display the preprint in perpetuity. It is made available under aCC-BY-NC 4.0 International license.

Figure S2
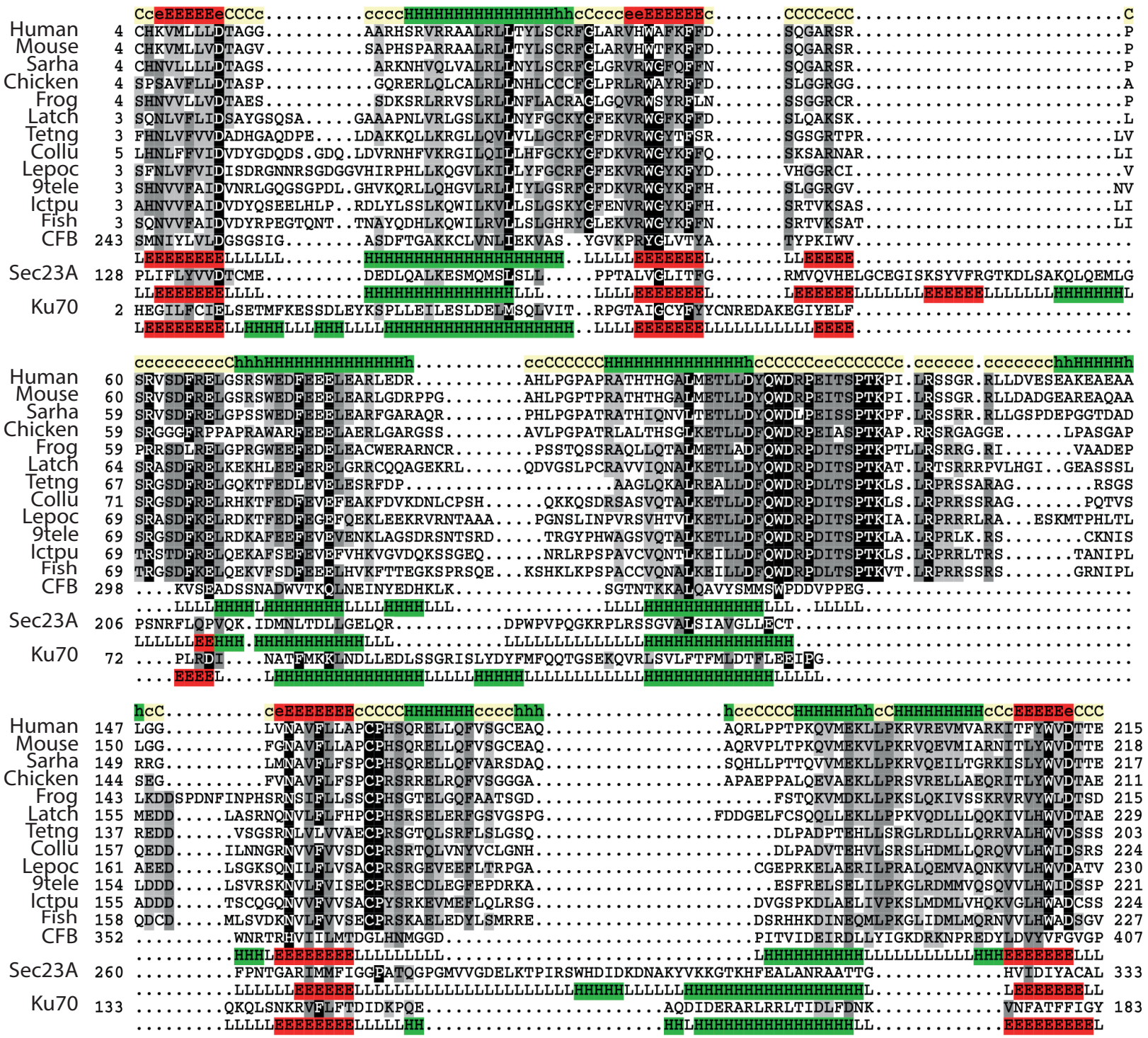


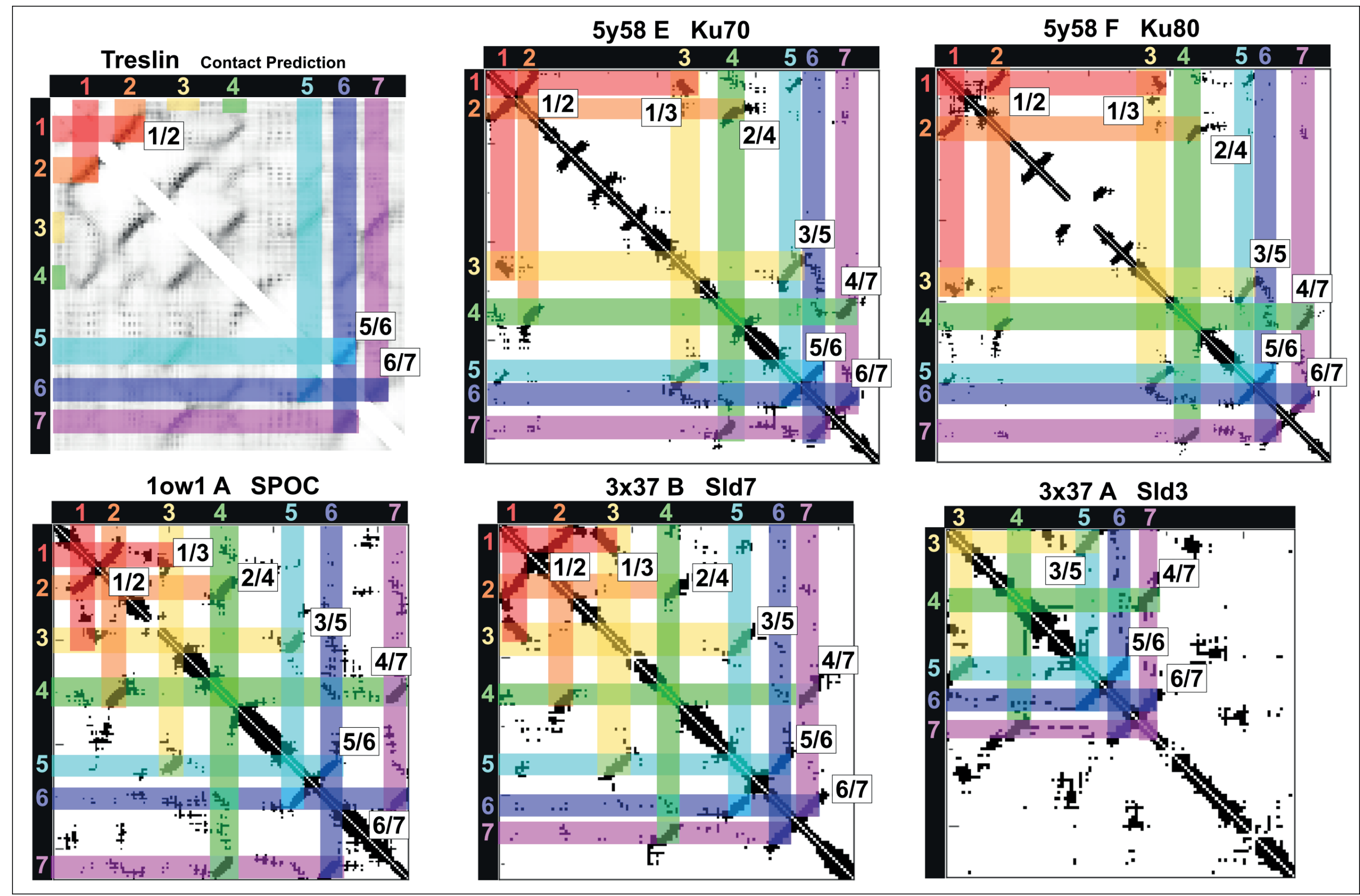


bioRxiv preprint doi: https://doi.org/10.1101/2021.07.24.453613; this version posted July 24, 2021. The copyright holder for this preprint (which was not certified by peer review) is the author/funder, who has granted bioRxiv a license to display the preprint in perpetuity. It is made available under aCC-BY-NC 4.0 International license.

A

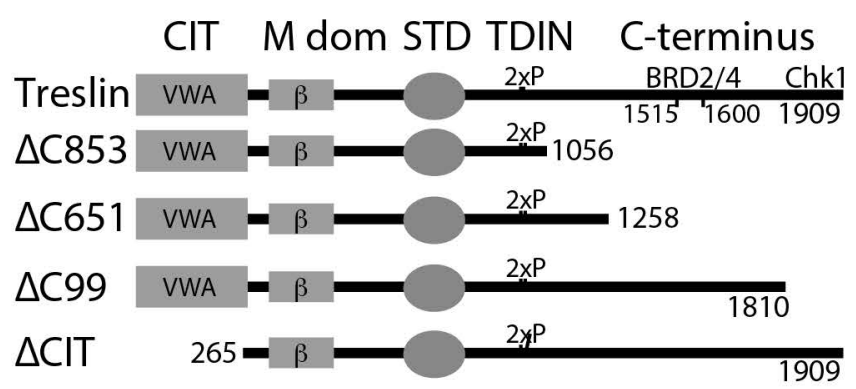

B

(i)

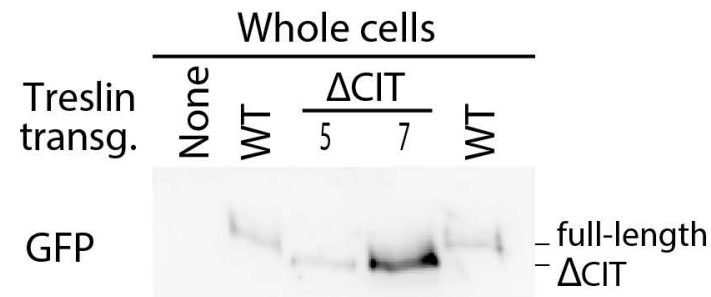

Load.

(Ponc.)

C

(i)

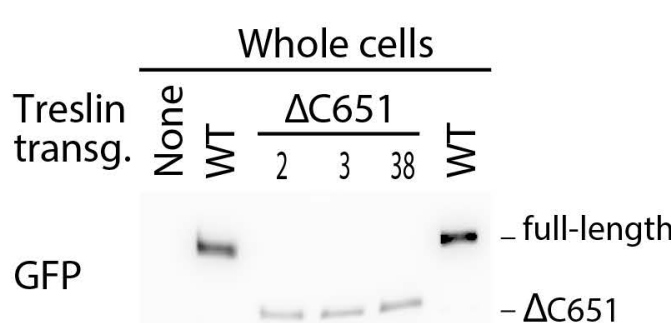

Load.

(Ponc.)

D

(i)

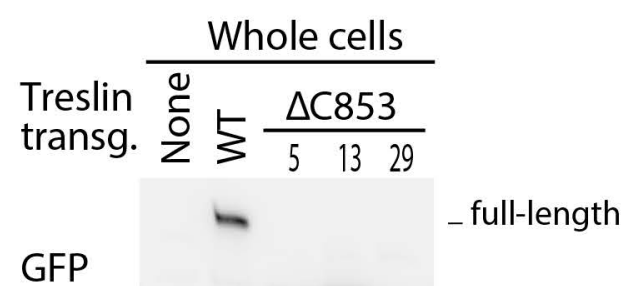

Load.

(Ponc.)

$-\Delta \mathrm{C} 853$
E

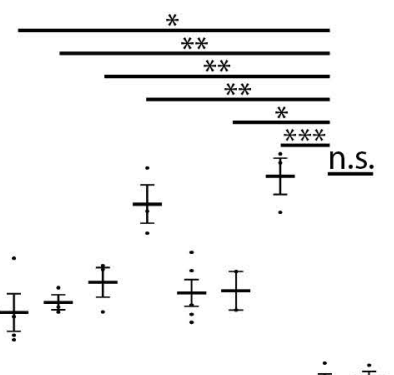

Figure S4

(ii) No trans- Treslin- $\frac{\text { Treslin- } \Delta \text { CIT }}{5}$

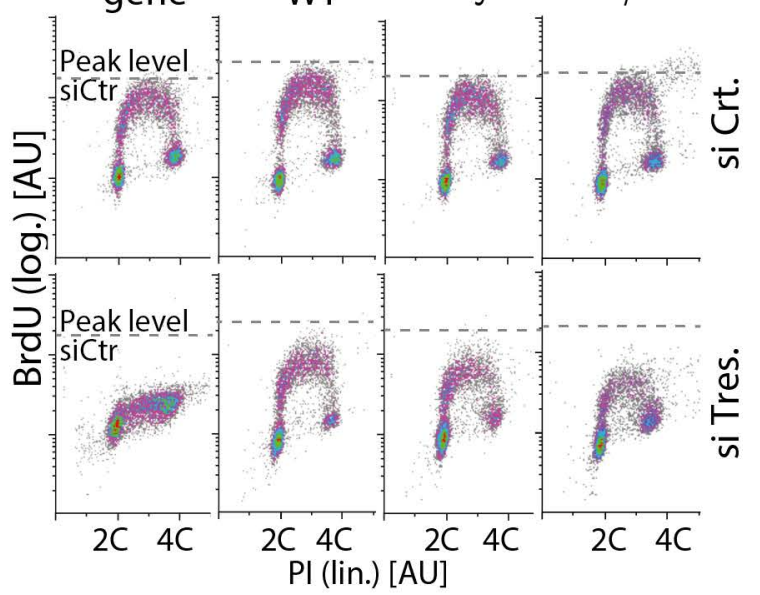

(ii)

\begin{tabular}{ccccc} 
No trans- & Treslin- & \multicolumn{3}{c}{ Treslin- $\Delta$ C651 } \\
\cline { 2 - 5 } gene & WT & 2 & 3 & 38
\end{tabular}

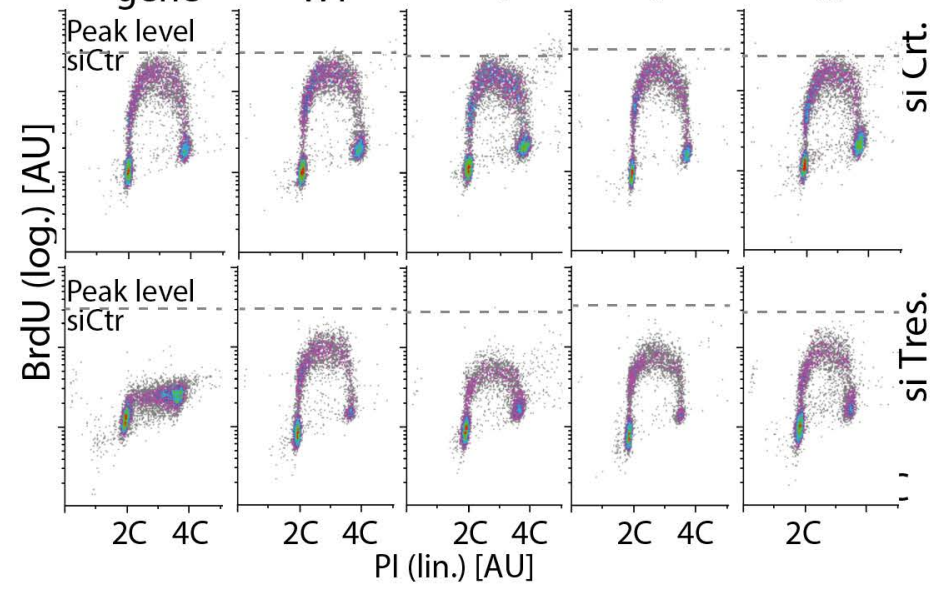

(ii)

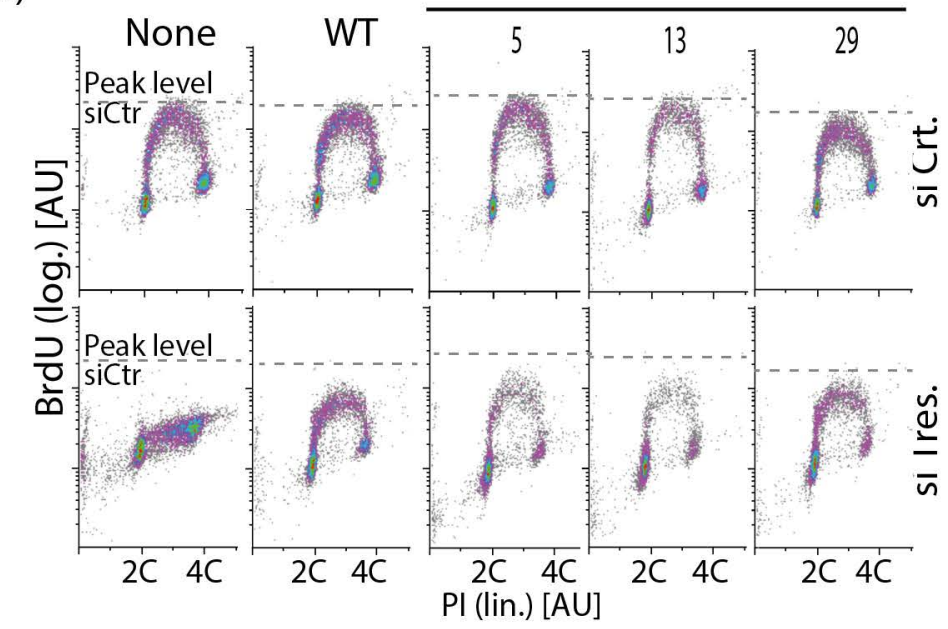


A

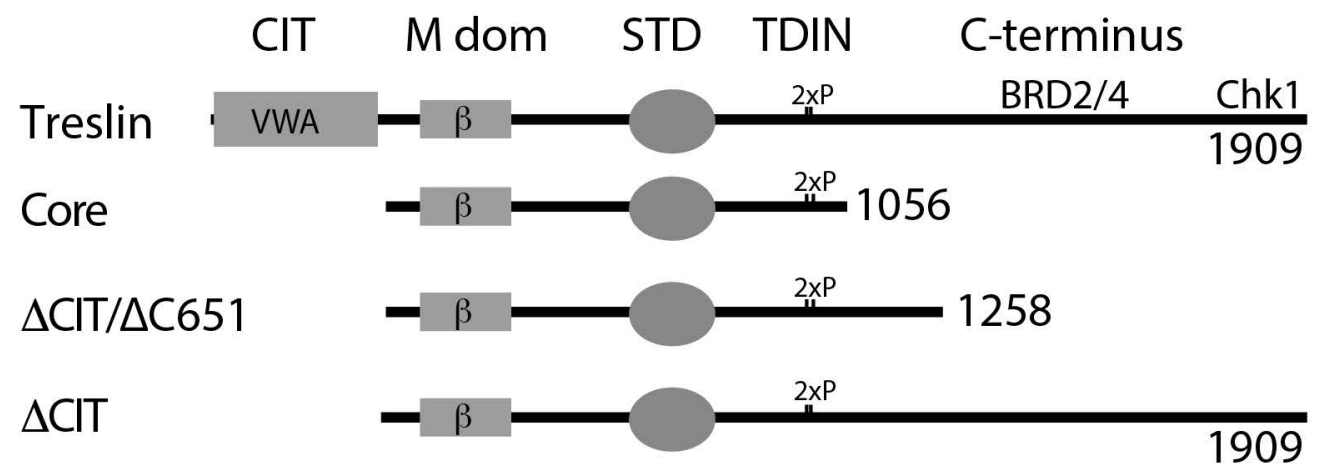

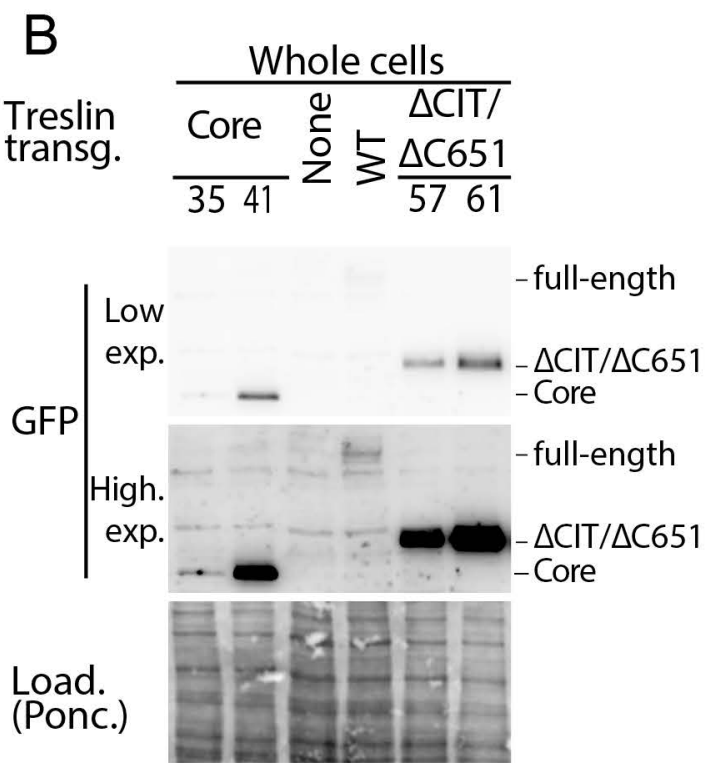

D

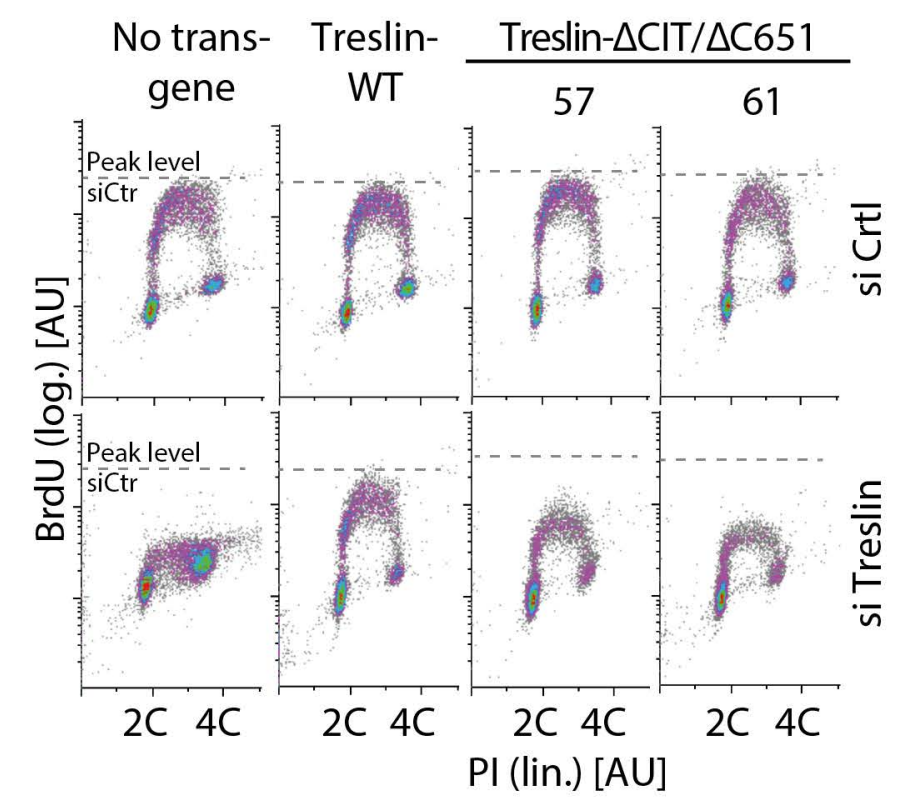

C No trans- Treslin-

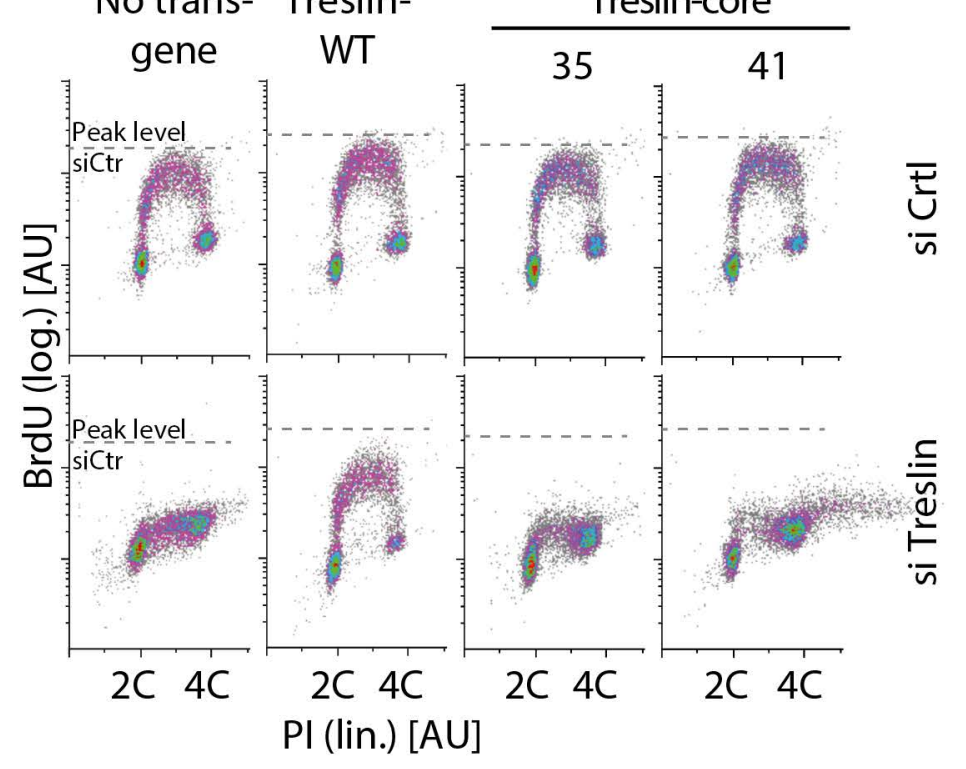

$\mathrm{E}$

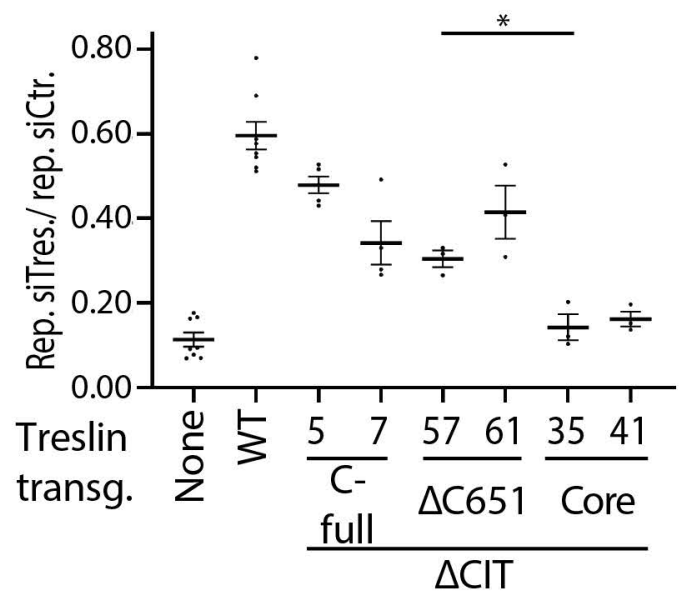


bioRxiv preprint doi: https://doi.org/10.1101/2021.07.24.453613; this version posted July 24, 2021. The copyright holder for this preprint (which was not certified by peer review) is the author/funder, who has granted bioRxiv a license to display the preprint in perpetuity. It is made available under aCC-BY-NC 4.0 International license.

A

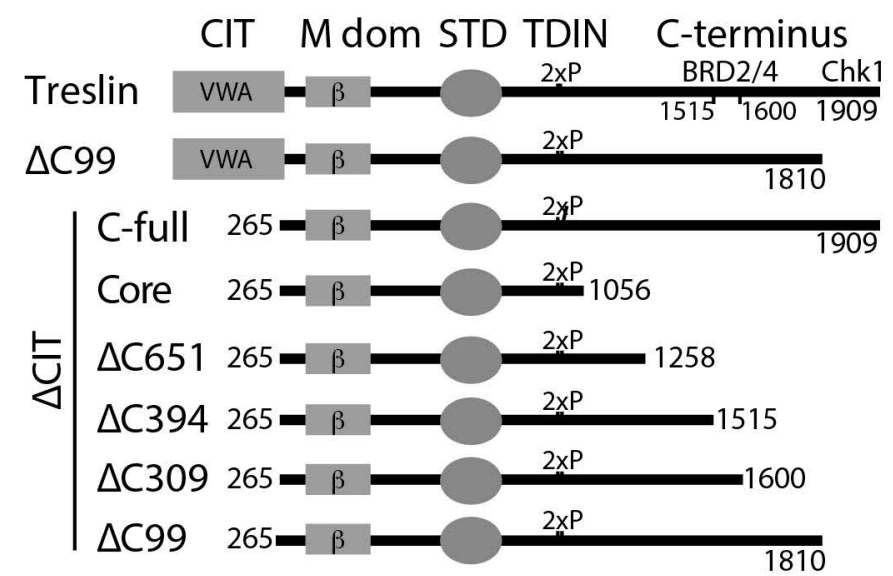

B

(i)

C

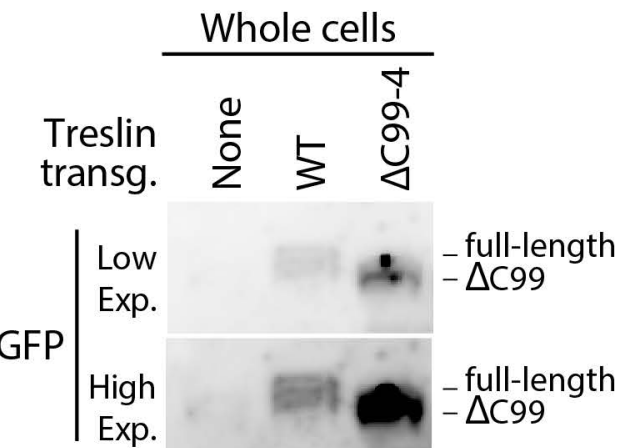

Load.

(Ponc.)
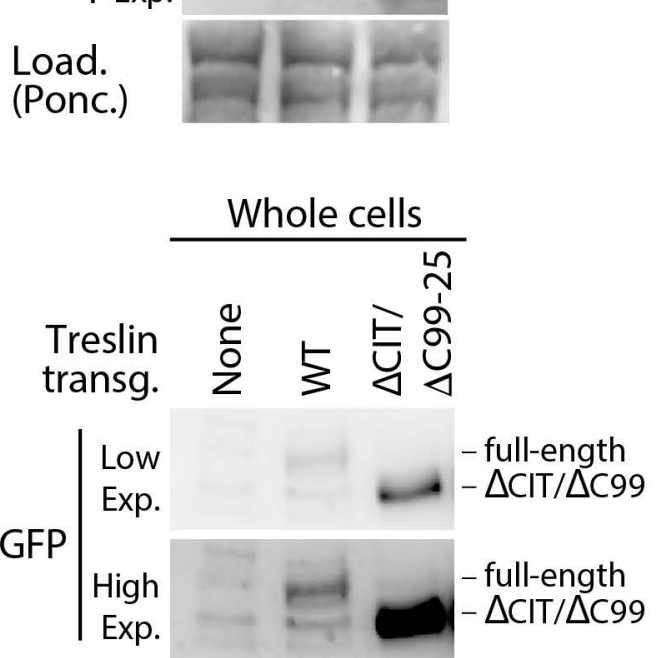

Load.

(Ponc.)

D

(i)

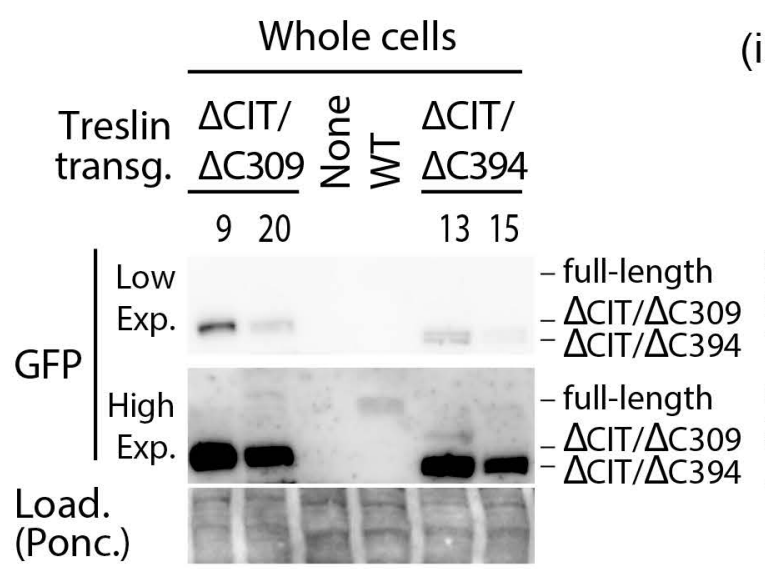

$\mathrm{E}$

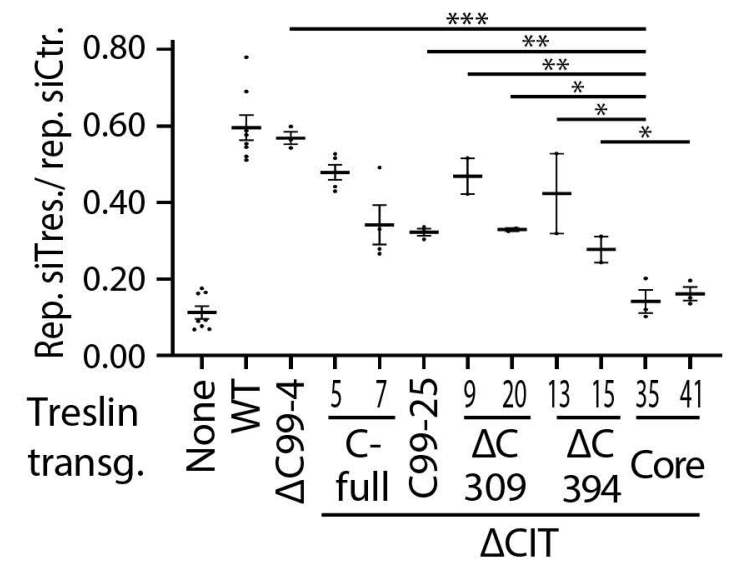

(ii)

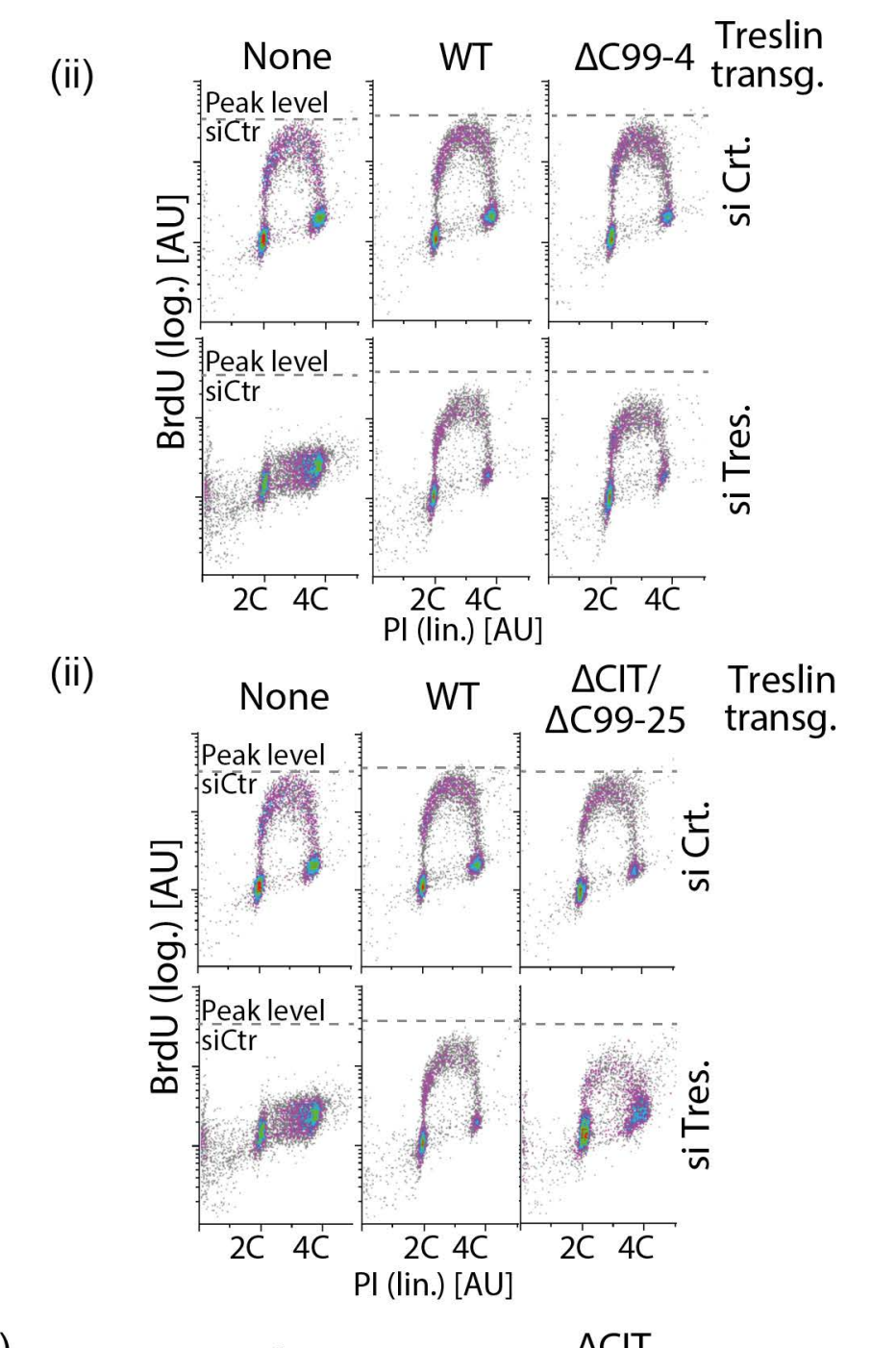

(ii)

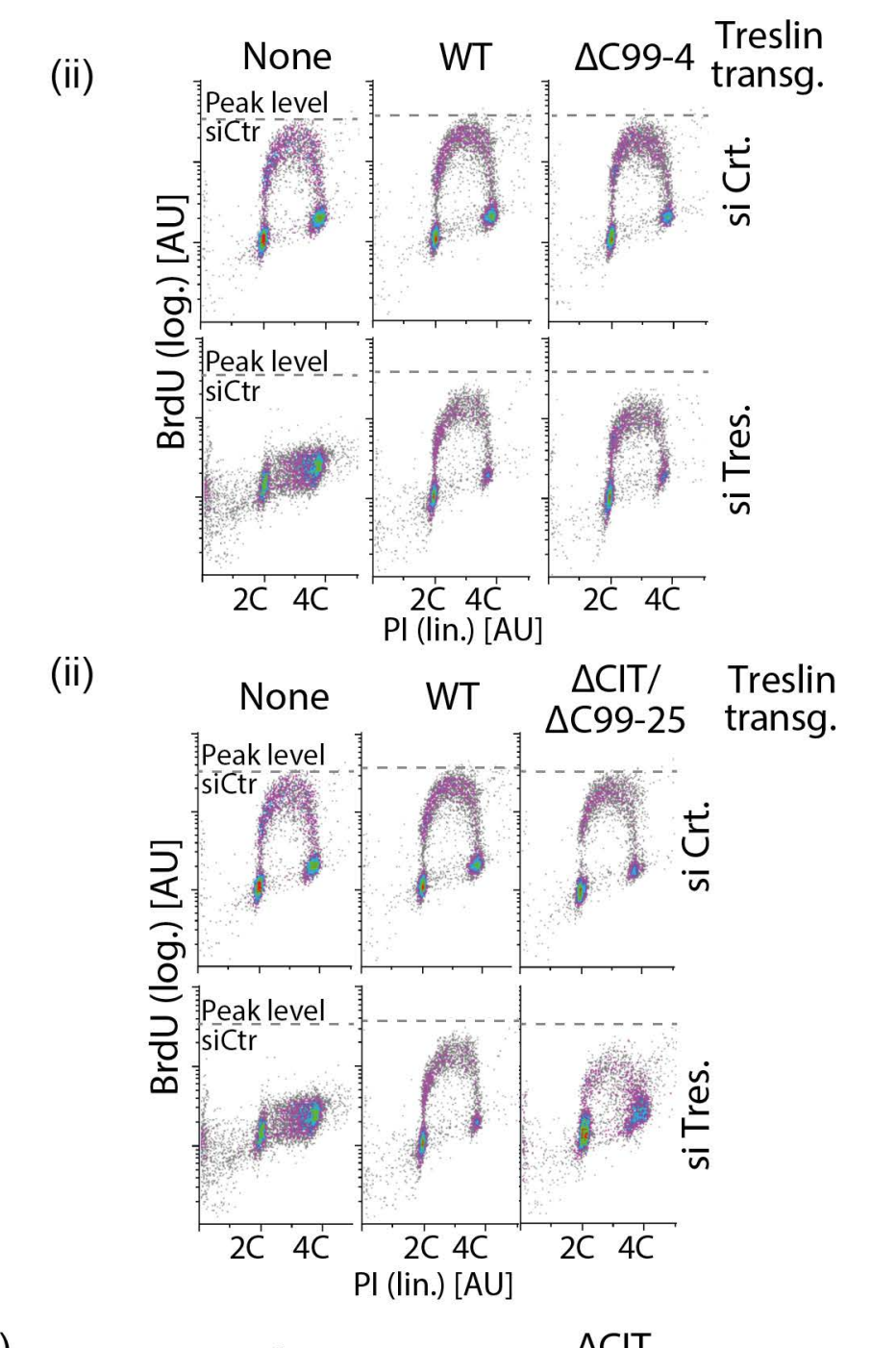

(ii) No trans- Treslin- $\Delta \mathrm{CIT}$

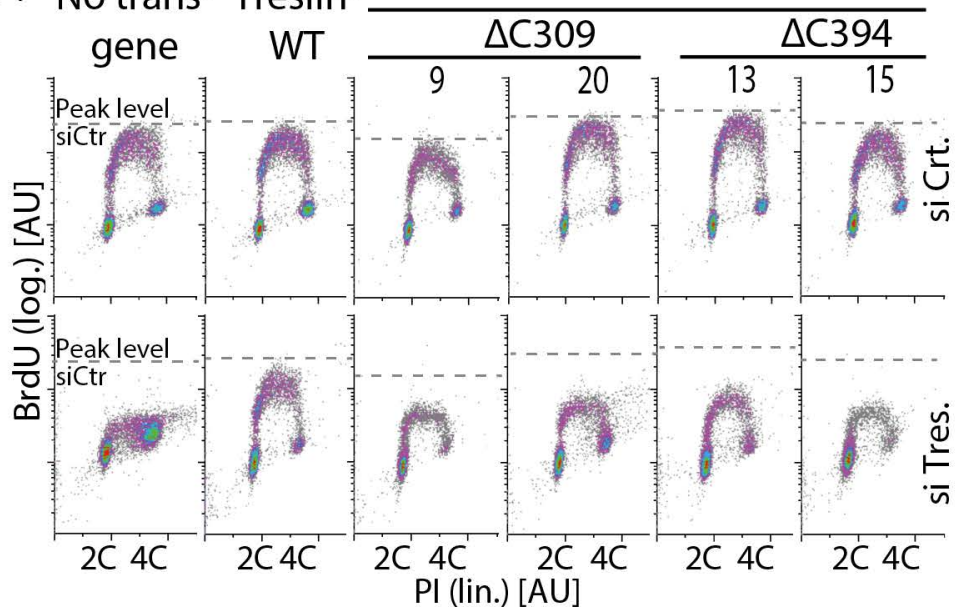




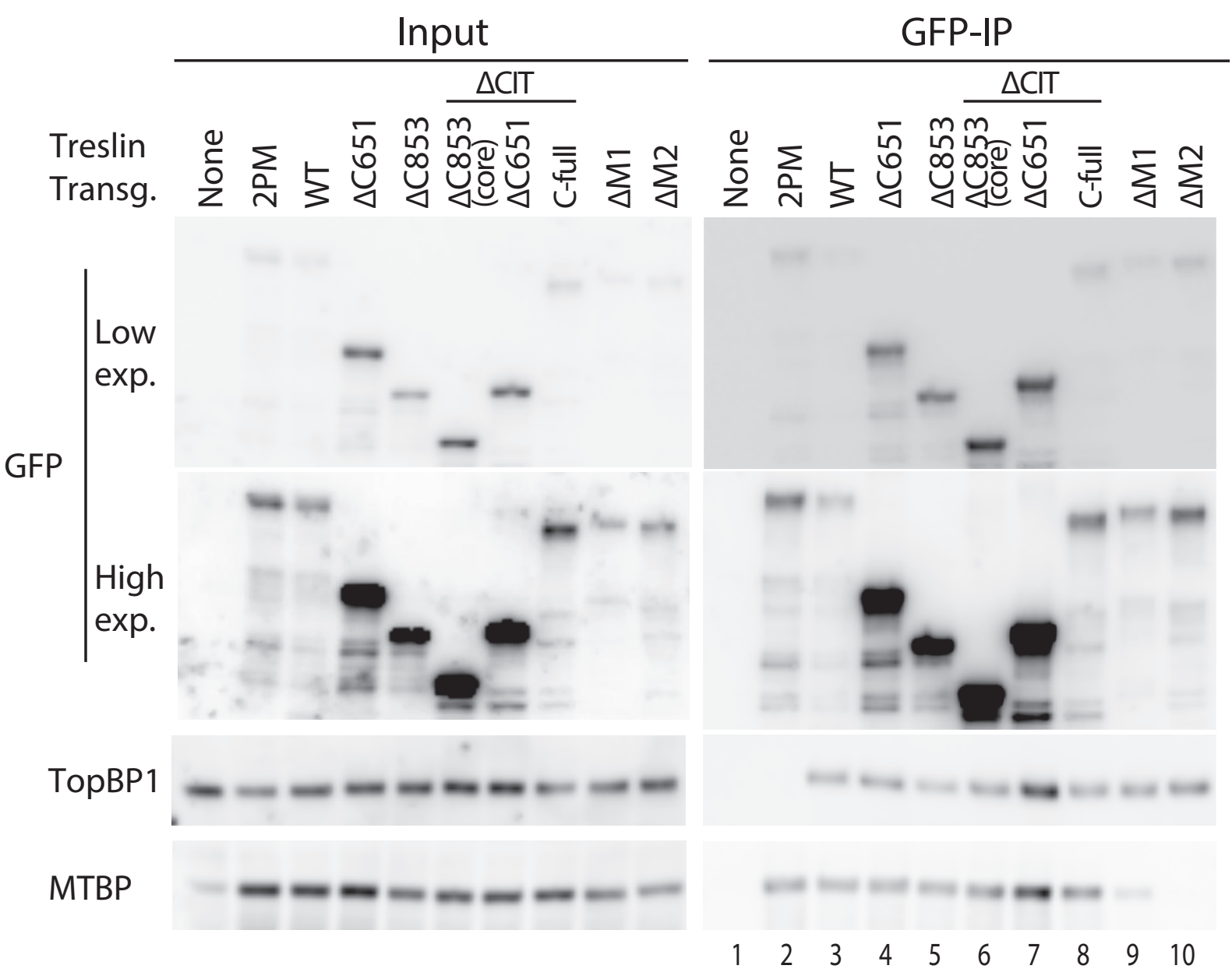

